\title{
A TAXONOMIC REVISION OF ACTINIDIACEAE OF VIETNAM
}

\author{
NGUYEN M. CUONG ${ }^{1}$, DJAJA D. SOEJARTO ${ }^{2} \&$ JIANGQIANG LI $^{3}$
}

\begin{abstract}
SUMMARY
Taxonomic study of morphological variability using multivariate analysis, together with field studies and literature review clarified the status of a number of paired species of Saurauia and Actinidia of Vietnam and resolved their correct nomenclature: Saurauia tristyla is different from S. roxburghii; Saurauia petelotii is not a synonym of $S$. fasciculata but is a separate species; Actinidia tonkinensis is a synonym of A. latifolia; Actinidia indochinensis is a distinct species, not a variety of A. callosa; Saurauia dillenioides is a synonym of $S$. armata; and Saurauia griffithii var. annamica is a synonym of S. napaulensis. Four taxa of Actinidia are newly recorded for Vietnam. The results of this study will allow us to better understand the conservation status of species of Actinidiaceae in Vietnam.
\end{abstract}

Key words: Actinidiaceae, Actinidia, Saurauia, Vietnam, multivariate analysis, taxonomy.

\section{INTRODUCTION}

The definition of the family Actinidiaceae was established in 1899 by Van Tieghem to include the genera Actinidia Lindl. and Saurauia Willd. (Van Tieghem, 1899). However, the correct authority citation for the family is Gilg \& Werdermann (1925), who used the family name correctly in its Latinized form. Van Tieghem used the French name Actinidiacées, which is not a validly published name (Article 18.4, Vienna Code; McNeill et al., 2006). The circumscription of Actinidiaceae has been much debated (Soejarto, 1980). Some taxonomists have recognized Actinidiaceae in a narrow sense to include only the genus Actinidia, and placed Saurauia in a distinct family, Saurauiaceae (Hutchinson, 1926: 177). In 1925, Gilg \& Werdermann accepted Actinidiaceae in a broader concept to include four genera: Actinidia, Saurauia, Clematoclethra (Franch.) Maxim., and Sladenia Kurz. Contemporary taxonomists recognize Actinidiaceae as comprising three genera, Actinidia, Saurauia, and Clematoclethra (Soejarto, 1980, 2004; Cronquist, 1981; Woodland, 2000; Dressler \& Bayer, 2004; Li et al., 2006), distributed in tropical Asia and America (Dressler \& Bayer, 2004; Soejarto, 2004). Estimates on the number of species within the family range from 325-360, of which more than 300 species of Actinidia and Saurauia occur in tropical and temperate East

1) University of Missouri at St. Louis, St. Louis, USA; present address: Herbarium, Cuc Phuong National Park, Nho Quan, Ninh Binh, Vietnam.

2) Corresponding author: Botany Department, Field Museum, 1400 S. Lake Shore Dr., Chicago, IL 60605-2496 and Program for Collaborative Research in the Pharmaceutical Sciences, College of Pharmacy, University of Illinois at Chicago, Chicago, IL 60612, USA; e-mail: dds@uic.edu.

3) Department of Systematics and Taxonomy, Wuhan Botanical Garden, the Chinese Academy of Sciences, Wuhan, Hubei 430074, People's Republic of China. 
Asia, while Clematoclethra is found only in China (Dressler \& Bayer, 2004; Soejarto, 2004). Phylogenetically, Actinidiaceae is now firmly placed in Ericales (Soltis et al., 2000; Anderberg et al., 2002), and is closely related to Roridulaceae, Sarraceniaceae, Clethraceae, Cyrillaceae, and Ericaceae; the six families form a monophyletic group (Soltis et al., 2000; Anderberg et al., 2002).

Both Actinidia and Saurauia occur in Vietnam and are recognized to belong to Actinidiaceae (Hô, 1999; Bân, 2003), but in older Indo-Chinese literature, both genera were placed under Dilleniaceae (Finet \& Gagnepain, 1907). Hô (1999) recognized six species of Actinidia from Vietnam - A. callosa var. indochinensis, A. chinensis (cultivated), A. coriacea, A. latifolia, A. petelotii, and A. tonkinensis, and five species of Saurauia - S. armata, S. fasciculata, S. macrotricha, S. napaulensis, and S. roxburghii. In a more recent checklist of the Flora of Vietnam, Nguyên Tiên Bân (2003) recognized five species of Actinidia - A. callosa var. indochinensis, A. coriacea, A. latifolia, A. petelotii, and A. tonkinensis (he excluded the cultivated species A. chinensis), and seven species of Saurauia - S. dillenioides, S. fasciculata, S. griffthii var. annamica, S. macrotricha, S. napaulensis, $S$. roxburghii, and S. tristyla.

A number of questions in the taxonomic delimitation of these Vietnamese taxa needed to be resolved: 1) Is $S$. roxburghii different from S. tristyla?; 2) Are S. fasciculata and S. petelotii separate species?; 3) Are A. latifolia and A. tonkinensis the same species?; 4) Is A. indochinensis a separate species or is it a synonym of A. callosa var. indochinensis?; 5) Is $S$. dillenioides different from S. armata?; 6) Is $S$. griffithii var. annamica a synonym of S. napaulensis? To answer these questions, an effort was made to revise the taxonomic treatment of members of Actinidiaceae of Vietnam, using a combination of fieldwork, examination of existing collections of Vietnamese Actinidiaceae, and laboratory and literature studies. The present paper is the result of that effort.

\section{MATERIAL AND METHODS}

For the present study, 382 Actinidiaceae collections in repository at the Missouri Botanical Garden (MO), Arnold Arboretum of Harvard University (A), Field Museum of Natural History (F), National Herbarium of the Netherlands in Leiden (L), New York Botanical Garden (NY), National Museum of Natural History (P), and National Herbarium of the Smithsonian Institution (US) were examined. This herbarium examination was supplemented by fieldwork in Vietnam during the summer of 2006, in which 51 additional collections of Actinidiaceae were gathered from various localities, including the following national parks: Cuc Phuong, Bach Ma, Tam Dao, and Hoang Lien Son National Parks. Duplicates of the field collections were deposited at the herbarium of the Institute of Ecology and Biological Resources (IEBR) of the Vietnamese Academy of Science and Technology in Hanoi, and at Missouri Botanical Garden. Fruits and flowers were preserved in $70 \%$ alcohol, while leaves were dried in silica gel for future molecular studies. The literature, particularly of Indo-Chinese holding, was searched.

Initially, specimens were sorted and grouped into provisional taxa based on variation in the shape of foliar blade, inflorescence size and type, flower colour, sepals, petals, stamens, ovary and the styles, and the indumentum type. Twenty-three selected characters that appeared to help distinguish between species were then measured for 
multivariate analysis, but indumentum type and pseudo-qualitative characters were excluded. Only fruits of Actinidia indochinensis and A. callosa were included for the analysis. For three other species pairs, too few fruiting specimens were available for analysis: Saurauia tristyla and S. roxburghii; S. petelotii and S. fasciculata; Actinidia latifolia and A. tonkinensis. The data were entered into an Excel file and transferred to SPSS 12.0, in order to perform data analysis using Bivariate Analyses, Principal Component Analyses (PCA), Cluster Analyses, and ANOVA test, and in order to understand the variation patterns of these species pairs. The following morphological characters were submitted to these analyses:
1. Petiole length
2. Leaf lamina length
3. Leaf lamina width
4. Leaf apex length
5. Number of pairs of lateral veins
6. Inflorescence length
7. Inflorescence width
8. Flower bud length
9. Flower bud width
10. Peduncle length
11. Pedicel length
12. Flower length
13. Flower width
14. Sepal length
15. Sepal width
16. Petal length
17. Petal width
18. Anther length
19. Style length
20. Ovary length
21. Ovary width
22. Fruit length
23. Fruit width

To determine dioecy within Actinidia latifolia, pollen grains from flowers in specimens collected in Vietnam in the summer of 2006, and from a single flower of Tsang 29907, the type of A. tonkinensis, were examined using a microscope connected to a digital camera to record the images.

\section{RESULTS OF MULTIVARIATE ANALYSES}

\section{Is Saurauia roxburghii Wall. different from S. tristyla DC.?}

Hô (1999) recognized $S$. roxburghii as occurring in Vietnam, and placed the names of S. oldhamii Hemsl., S. poilanei Gagnep., and S. thorellii Gagnep. in synonymy. Nowhere in the book is the Latin binomial $S$. tristyla found. The illustration (Fig. 1649) on p. 410 depicts $S$. tristyla. Thus, the reference to $S$. roxburghii by Hô is a case of misidentification. Saurauia tristyla has 3 styles, free for most of their length, while $S$. roxburghii has 4 or 5 styles (see also Dyer, 1874: 287), which are connate at base $0.6-0.7$ of their length. Bân (2003), however, listed both species as occurring in Vietnam.

Analyses of variation - Bivariate analyses showed that many characters do not closely overlap between the two species. In the PCA (Fig. 1), the first axis accounted for $57.4 \%$ of the total variance, with sepal length and number of pairs of lateral veins (a negative value) being the major contributors to the variation, while the second axis accounted for $16.9 \%$ of the total variance, with apex length (a negative value) and inflorescence length being particularly important. The third axis accounted for $8 \%$ of the total variation, with major contributions coming from lamina length and ovary 


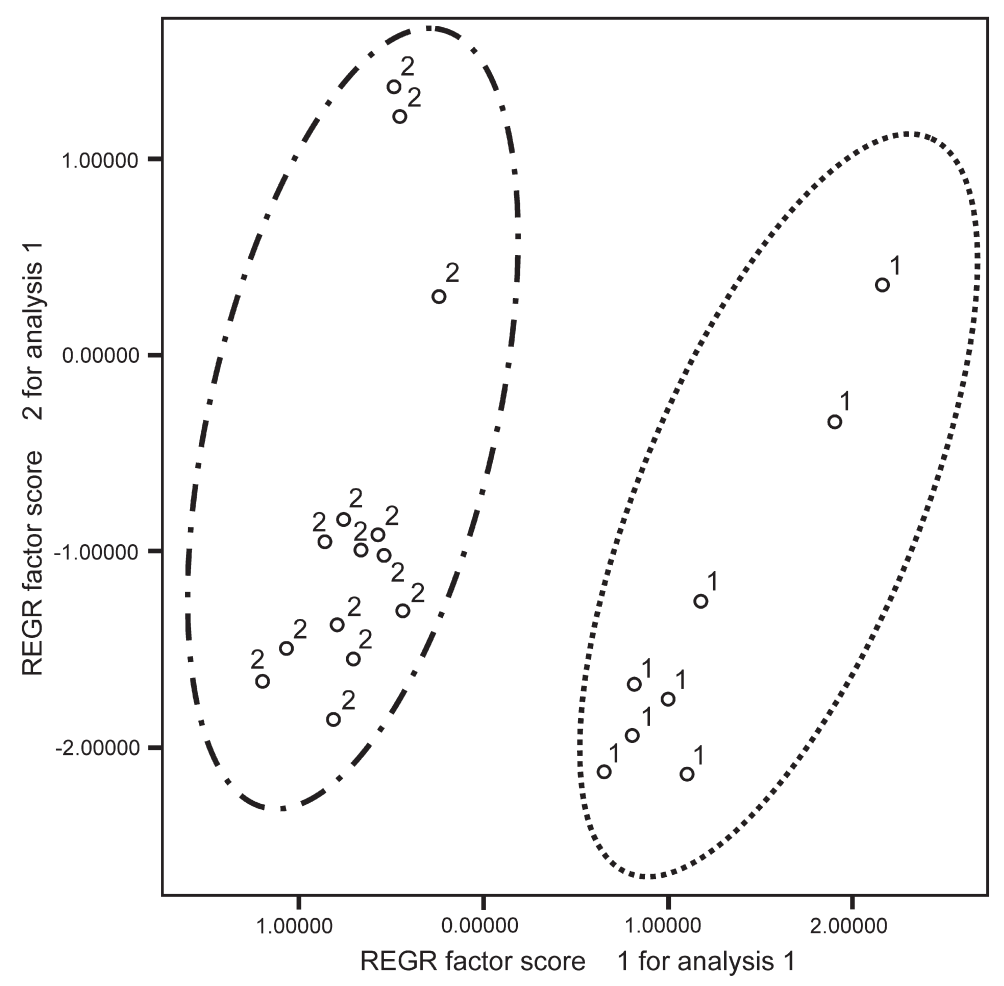

Fig. 1. PCA - two-dimensional scatter plots of variation in (1) Saurauia tristyla DC. and (2) S. roxburghii Wall.

length. The scatter plots (PCA) (Fig. 1) showed two distinct groups of specimens, suggesting that $S$. tristyla is distinct from S. roxburghii. In the Cluster Analysis (Fig. 2), however, specimens of $S$. roxburghii and $S$. tristyla form three or four clusters (see below). One-way ANOVA test compared mean values of two putative character groups and proved that many characters differed significantly at the level $0.001<\mathrm{P}<0.05$.

Discussion - The results of the bivariate analyses show that most characters do not overlap. PCA scatter plot results suggest that S. tristyla is clearly distinct from

Table 1. Differences between Saurauia tristyla DC. and S. roxburghii Wall.

\begin{tabular}{lll}
\hline Characters & S. tristyla & S. roxburghii \\
\hline Inflorescence & $1.2-3 \mathrm{~cm}$ long & $1.5-8 \mathrm{~cm}$ long \\
Peduncle & $0.1-0.2 \mathrm{~cm}$ long & $0.6-6 \mathrm{~cm} \mathrm{long}$ \\
Flower size & $5.5-10$ by $6-8.5 \mathrm{~mm}$ & $5-7.5$ by $4-6 \mathrm{~mm}$ \\
Sepal size & $5-7.5$ by $4-5.5 \mathrm{~mm}$ & $4-5$ by $3-4.5 \mathrm{~mm}$ \\
Petal size & $7-9$ by $4-5 \mathrm{~mm}$ & $5-7$ by $3-4 \mathrm{~mm}$ \\
Styles & Separate from base, $4.5-7 \mathrm{~mm}$ long & Connate basally $1 / 2$ to $3 / 4$ their \\
& & length, $1.5-3.2 \mathrm{~mm}$ long \\
\hline
\end{tabular}




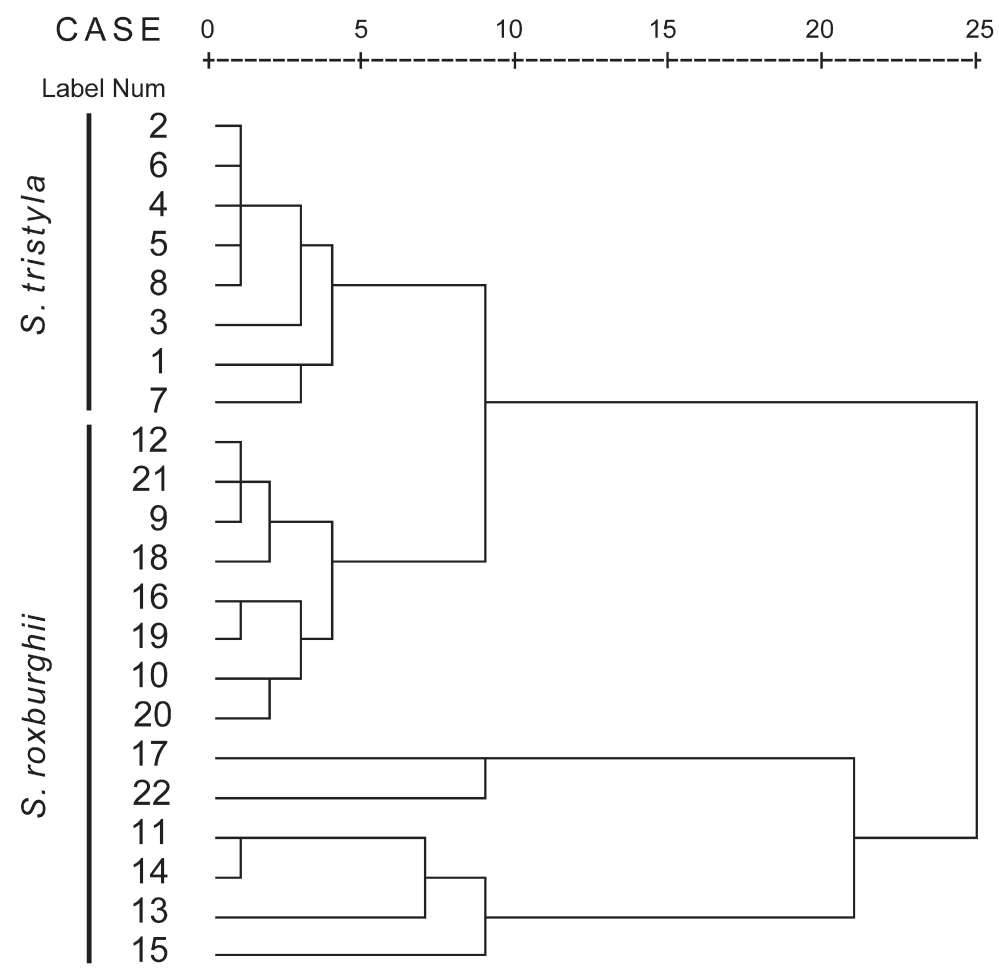

Fig. 2. Dendrogram of Saurauia tristyla DC. and S. roxburghii Wall.

S. roxburghii (Fig. 1). On the other hand, the dendrogram (Fig. 2) suggests that either there are a number of taxa, or S. tristyla is to be included in $S$. roxburghii. The pattern in the dendrogram can perhaps be explained by the fact that some specimens of S. roxburghii have inflorescences about the same length as those of S. tristyla (Table 1). Perusal of the literature and specimens showed that S. tristyla differs from S. roxburghii in the length of its peduncles, flower buds, flowers, anthers, and styles; the connation of the styles is an important distinguishing feature. All told, the evidence suggests that S. tristyla should be kept separate from S. roxburghii.

\section{Are Saurauia fasciculata Wall. and S. petelotii Merr. separate species?}

Both Hô (1999) and Bân (2003) included Saurauia petelotii as a synonym of S. fasciculata. In resolving the question of this synonym, 15 collections of the two species were assembled for analysis: 5 of $S$. fasciculata and 10 of S. petelotii.

Analyses of variation - Bivariate analyses showed that many characters did not overlap between the two species. In the PCA, $73 \%$ of the total variation was accounted for by the first axis, with major contributions coming from flower bud width and lamina width (a negative value) being particularly important, while $10.5 \%$ of the total variation was accounted for by the second axis, with pedicel length and ovary length 


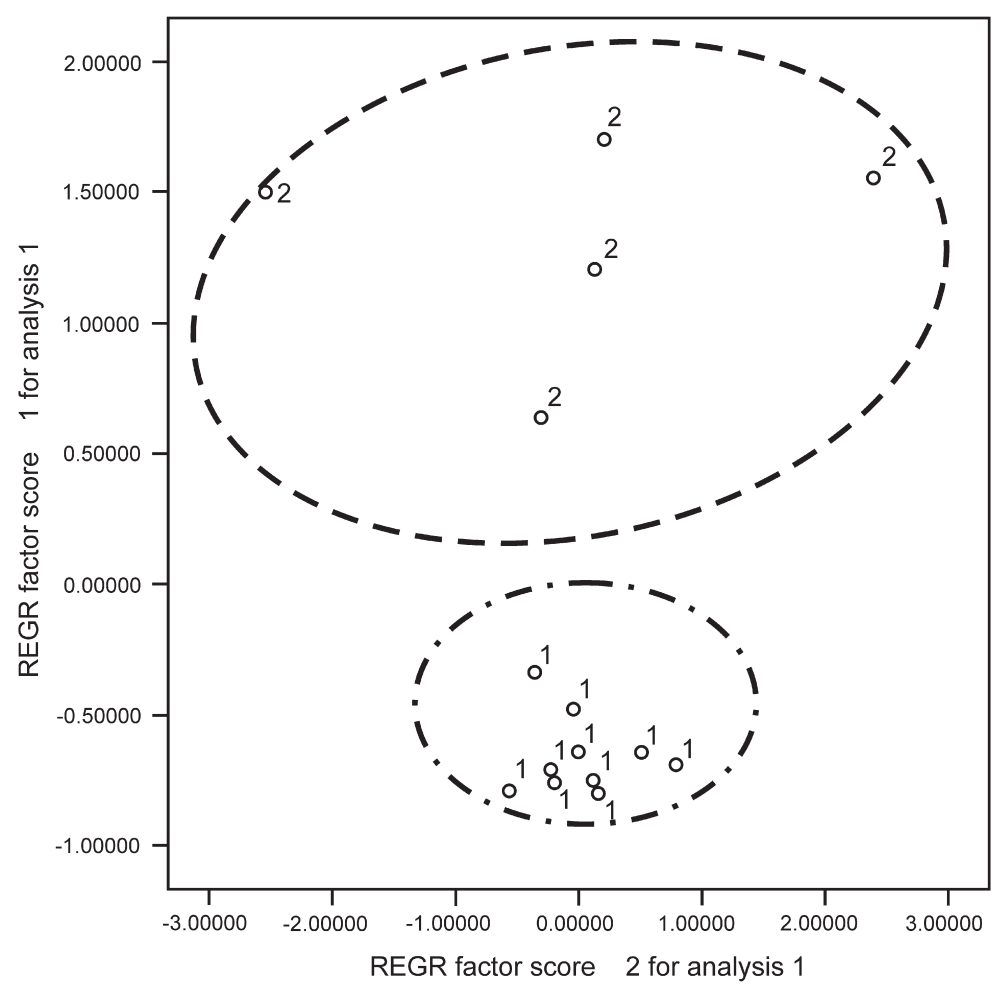

Fig. 3. PCA - two-dimensional scatter plots of (1) Saurauia petelotii Merr. and (2) S. fasciculata Wall.

(a negative value) being particularly important. The third axis accounted for $7.3 \%$ of the total variation, with lamina length and flower length (a negative value) being the contributors. The scatter plots (Fig. 3) show two separate groups of specimens, suggesting that $S$. petelotii is distinct from $S$. fasciculata, although one group is rather diffuse. The dendrogram (Fig. 4) showed two clearly distinct groups, and in a one-way ANOVA test, most characters showed significant differences.

Table 2. Differences between Saurauia petelotii Merr. and S. fasciculata Wall.

\begin{tabular}{lll}
\hline Characters & S. petelotii & S. fasciculata \\
\hline Leaf & Obovate to rounded-ovate, & Elliptic-oblong to elliptic-lanceolate, \\
& $12-29$ by $6.5-12.5 \mathrm{~cm}$ & $10-25$ by $3-8 \mathrm{~cm}$
\end{tabular}




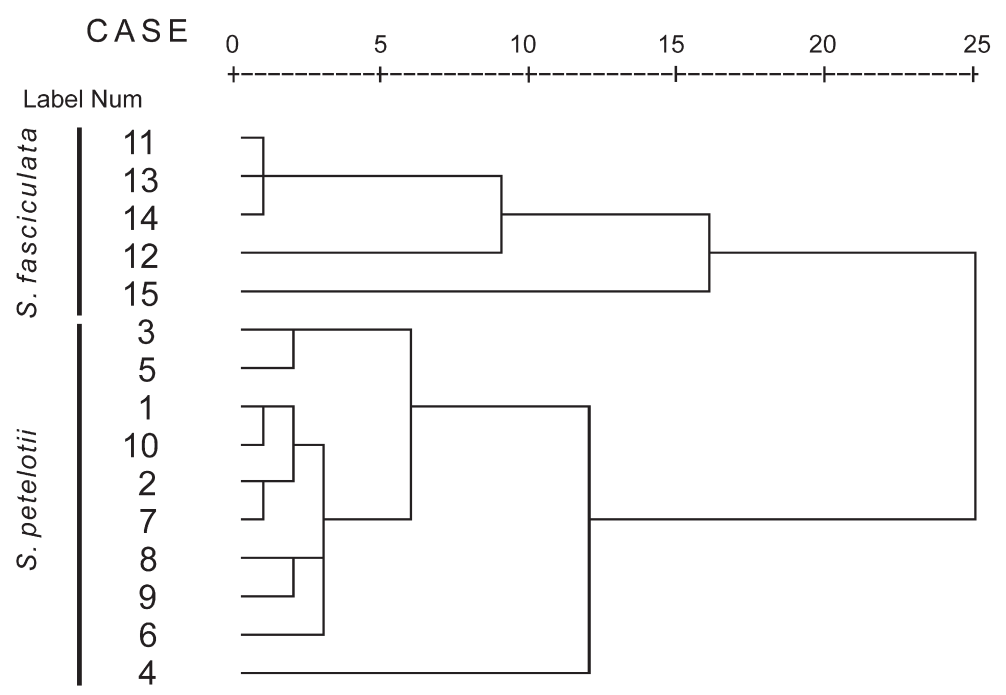

Fig. 4. Dendrogram of Saurauia petelotii Merr. and S. fasciculata Wall.

Discussion - The results of the bivariate analyses show that many characters do not overlap. The result of the PCA scatter plot and the cluster analysis show that $S$. petelotii is clearly different from S. fasciculata (Fig. 3, 4). Leaf length and width, and inflorescence, peduncle, flower, and style length are particularly important characters separating the species (Table 2). Merrill (1924) and Paul (1993) have also suggested that the two species are distinct. Geographically, S. petelotii grows in southwest China, Vietnam, and northwest Thailand, while $S$. fasciculata is known from Bhutan and Assam.

\section{Is Saurauia dillenioides Gagnep. different from S. armata Kurz?}

Gagnepain (1938) contrasted his S. dillenioides (based on type specimens collected in North Vietnam) with $S$. cerea Griff. ex Dyer (1874) (based on type specimens collected in the Himalayas), pointing out that sepals of the former were sparsely hairy dorsally, while those of the latter were covered by dense, scaly indumentum. Hô (1999) placed S. dillenioides as a synonym under $S$. armata, which Kurz (1877) described based on type specimens collected in Myanmar. Bân (2003), however, listed S. dillenioides as a distinct species, giving ' $S$. armata apud Hô' as a synonym, and did not recognize S. armata Kurz as occurring in Vietnam. In his account of Actinidiaceae from India, Paul (1993) recognized $S$. armata Kurz, and listed $S$. cerea and S. dillenioides as synonyms. Liang (1984), on the other hand, recognized S. dillenioides and S. armata as two distinct species.

Examination of the available material collected in Vietnam and identified as $S$. armata Kurz - but also annotated as S. dillenioides Gagnep. -, and material from China identified as $S$. cerea Gagnep., indicates that $S$. dillenioides and $S$. armata Kurz are one and the same (Table 3), with the correct name being S. armata Kurz (an earlier name), while the Indian $S$. cerea appear to represent a separate species. 
Table 3. Similarities between Saurauia dillenioides Gagnep. and S. armata Kurz.

\begin{tabular}{|c|c|c|}
\hline Characters & S. dillenioides & S. armata \\
\hline Indumentum & Strigose and puberulent & Appressed scales and tomentose \\
\hline Leaf & $\begin{array}{l}\text { Obovate to broadly obovate, } \\
20-32 \text { by } 17-20 \mathrm{~cm} \text {, (main and lateral) } \\
\text { veins with strigose indumentum, } \\
\text { lateral veins } 17-21 \text { pairs }\end{array}$ & $\begin{array}{l}\text { Broadly ovate to obovate-oblong, } \\
15-35 \text { by } 8-17 \mathrm{~cm} \text {, main and lateral } \\
\text { veins with scattered stiff scales, } \\
\text { lateral veins } 18-21 \text { pairs }\end{array}$ \\
\hline Inflorescence & Solitary or clusters & Solitary or clusters \\
\hline Flower size & $1.5-2 \mathrm{~cm}$ diameter & C. $1.5 \mathrm{~cm}$ diameter \\
\hline Sepal size & $\begin{array}{l}7-10 \text { by } 5-8 \mathrm{~mm} \text {, abaxially tomentose to } \\
\text { scattered strigose, adaxially puberulent }\end{array}$ & $\begin{array}{l}\text { C. } 10 \text { by } 8 \mathrm{~mm} \text {, abaxially tomentose } \\
\text { and with pointed scales, adaxially } \\
\text { tomentose }\end{array}$ \\
\hline Petal size & $\begin{array}{l}\text { Obovate; white, reddish at base, } \\
10-15 \text { by } 8-9 \mathrm{~mm} \text {, glabrous }\end{array}$ & $\begin{array}{l}\text { Obovate; white, reddish at base, } \\
\text { c. } 12 \text { by } 8 \mathrm{~mm} \text {, glabrous }\end{array}$ \\
\hline Stamens & Numerous & Numerous \\
\hline Styles & 5 & 5 \\
\hline Ovary & Globose, densely tomentose & Globose, densely tomentose \\
\hline Fruit & Ovoid, pubescent & Ovoid, pubescent \\
\hline
\end{tabular}

\section{Is Saurauia griffithii Dyer var. annamica Gagnep. a synonym of $S$. napaulensis DC.?}

Gagnepain (1938) described S. griffithii var. annamica based on type specimens collected from Vietnam. Hô (1999) did not list this taxon as occurring in Vietnam, but Bân (2003) recognized S. griffithii var. annamica and listed it in his Checklist.

Discussion - Gagnepain (1938) described S. griffithii var. annamica, listing the presence of pubescence on the lower leaf surface, on the inflorescences, and on the adaxial sepal surfaces as a distinguishing character. However, examination of the syntypes of S. griffithii var. annamica showed that pubescence, and other characters, fall within the range of variation of $S$. napaulensis, namely, abundant tomentose pubescence on the lower surface of the leaf lamina, scattered strigose and tomentose indumentum on the inflorescences, and scattered puberulence on the adaxial surface of the sepals. Hence, S. griffithii var. annamica is placed as a synonym of S. napaulensis in the present treatment.

\section{Are Actinidia latifolia (Gardner \& Champ.) Merr. and A. tonkinensis H.L. Li the same species?}

Li (1943) described A. tonkinensis based on a type specimen (Tsang 29907) collected in Tonkin (North Vietnam). He recognized that A. tonkinensis is closely related to A. latifolia, but differing from it in having an acute or broadly acute lamina base (not cordate or broadly rounded), the lower surface has fewer stellate hairs, and the inflorescences longer, with more numerous and smaller flowers. In his 1952 revision of Actinidia, Li made an erroneous combination, A. latifolia (Gardner \& Champ.) Merr. var. indochinensis H.L. Li; incorrectly citing his 1943 species (A. tonkinensis) based on 


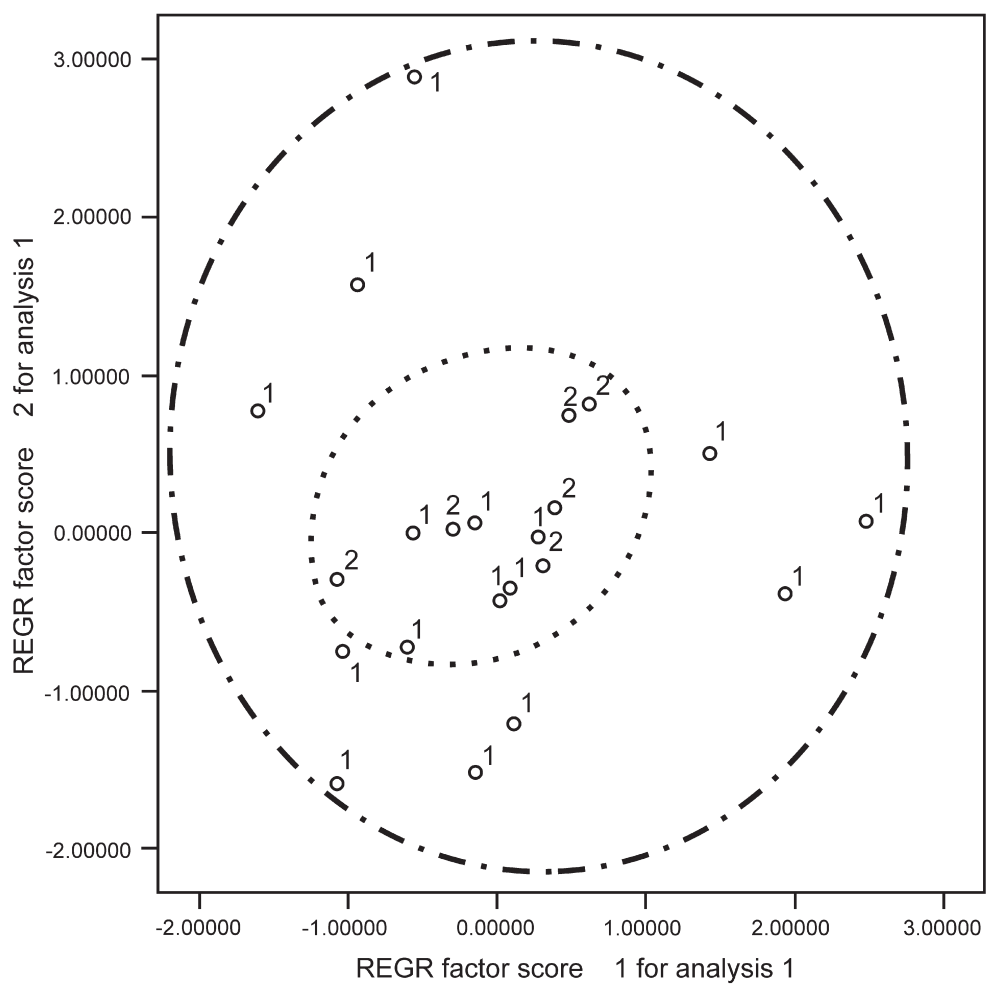

Fig. 5. PCA - two-dimensional scatter plots of (1) Actinidia latifolia (Gardner \& Champ.) Merr. and (2) A. tonkinensis H.L. Li.

Tsang 29907 as A. indochinensis (see further below). Both Hô (1999) and Bân (2003) accepted A. tonkinensis H.L. Li as a distinct species, while Liang (1984) included it as a synonym of $A$. latifolia.

Analyses of variation - Only the type of A. tonkinensis was initially identified as belonging to this species; however, five other collections were later also determined to belong to A. tonkinensis. In total, 22 collections were included in this study.

Bivariate Analyses showed that all characters (lamina length vs width, inflorescence length vs width), and others overlap between the two species. In the PCA analysis only $35.9 \%$ of the total variation is located along the first axis; sepal length and the number of lateral veins being particularly important. Of the total variance, $19.4 \%$ is accounted for by the second axis; inflorescence length and flower bud width (a negative value) being particularly important. The third axis accounted for $9.3 \%$ of the total variation, with major contributions from pedicel length and ovary width (a negative value). The scatter plot (Fig. 5) showed no distinct groupings, suggesting that only a single species is involved. When grouping using Cluster Analysis, specimens of A. tonkinensis were interposed with those of A. latifolia in the dendrogram (Fig. 6). In a one-way ANOVA test, variation of most characters lacked significance at level $0.05<\mathrm{P}<0.988$. 


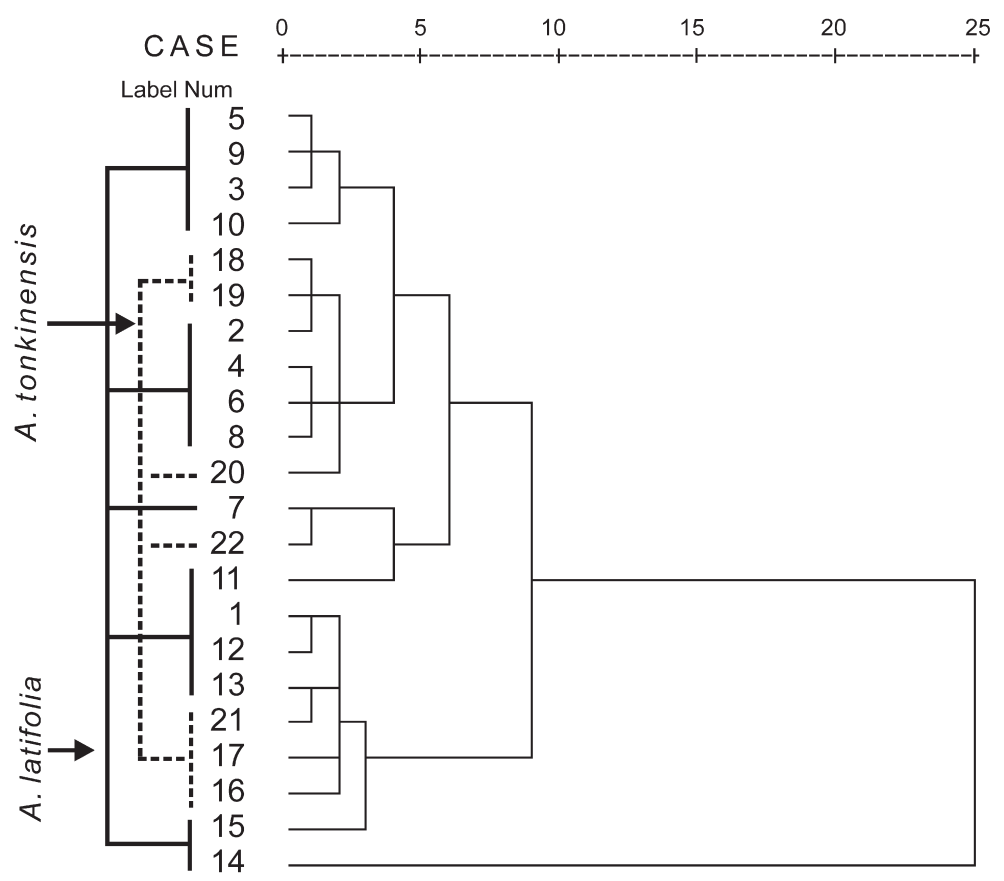

Fig. 6. Dendrogram of Actinidia latifolia (Gardner \& Champ.) Merr. and A. tonkinensis H.L. Li.

Examination of pollen grains from two individual specimens initially identified as A. latifolia and A. tonkinensis suggested that differences between the species appeared to be connected with dioecy. Flowers of Cuong 2050 (A. latifolia) produce sterile grains, which did not absorb cotton blue stain in lacto-phenol test (Fig. 7c, e). On the other hand, Cuong 2048, collected in the same locality as Cuong 2050 and initially identified as A. tonkinensis, demonstrated to have functional (fertile) pollen, absorbing cotton blue in lacto-phenol test (Fig. 7f). Pollen from Tsang 29907, an isotype of A. tonkinensis, also has functional pollen (Fig. 7d). The gynoecia of Cuong 2050 (Fig. 7a) are well developed with long styles (3-4 mm long), while those of Cuong 2048 (Fig. 7b) lack styles or have only very short styles. The ovaries of Cuong 2050 are 3-4 times larger than those of Cuong 2048.

These data suggest that A. latifolia and A. tonkinensis represent only a single species, the differences between the flowers of the two being linked to their breeding system; Actinidia is a dioecious taxon. The differences between these two presumed species that Li (1943) observed, smaller flowers and longer inflorescences in A. tonkinensis (staminate individuals) compared with those of A. latifolia (pistillate individuals), are also due to dioecy.

Discussion - The results of the bivariate analyses show clearly that most characters overlap. PCA scatter plot result suggest that A. latifolia and A. tonkinensis belong to a single species; all the specimens included in the analysis form only a single group (Fig. 5). The result of the cluster analysis show that specimens of A. tonkinensis are 

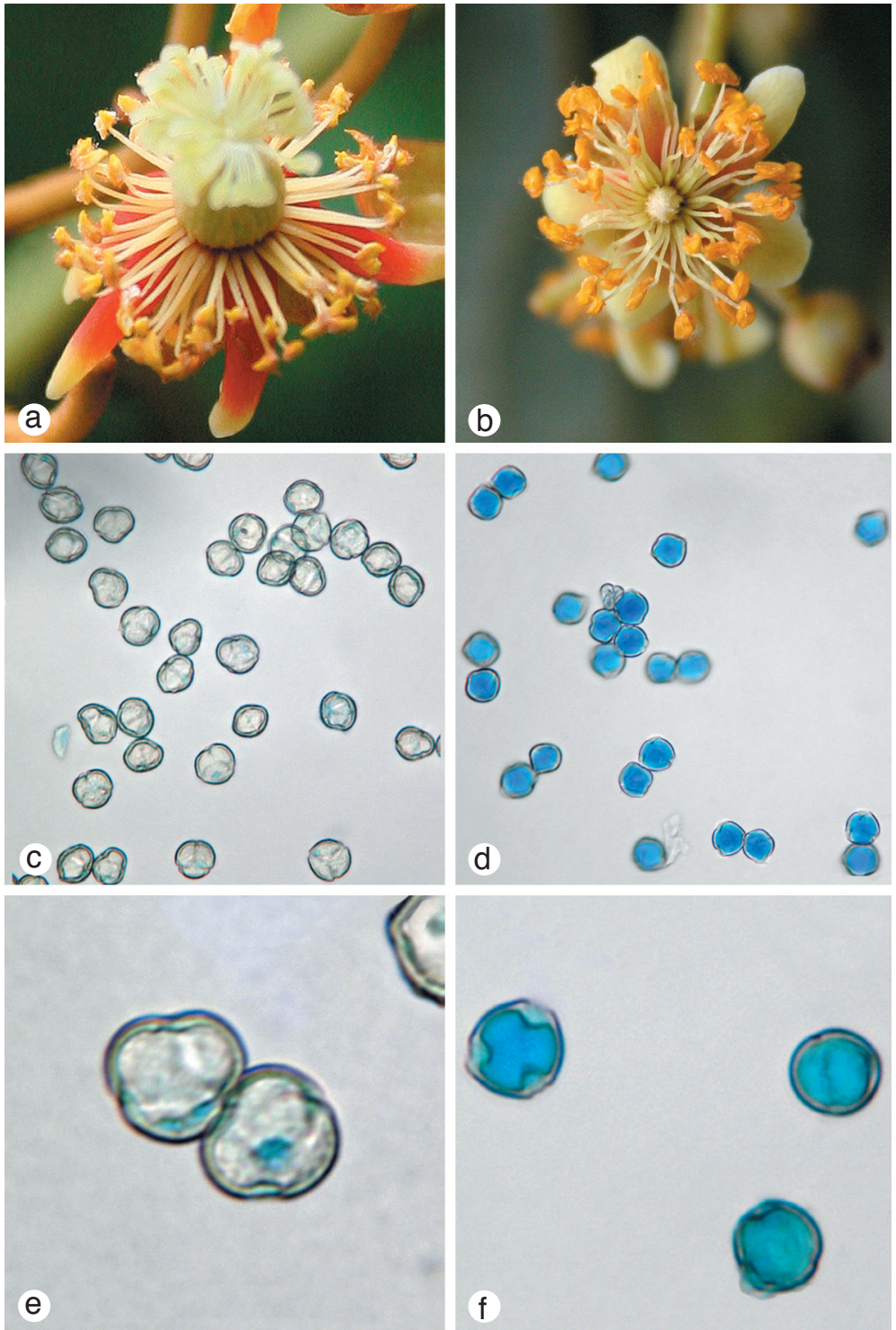

Fig. 7. Pollen analysis of Actinidia latifolia (Gardner \& Champ.) Merr. 7a, c (87x) and e (330x) from female flower (Cuong 2050); 7b, f (220x) from staminate flower (Cuong 2048); 7d (65x) from flower of A. tonkinensis Li (Tsang 29907), and also Cuong 2048.

intermingled with A. latifolia (Fig. 6). Comparison of the flowers of A. latifolia and A. tonkinensis show that the latter has been described based on a staminate plant, which has a small ovary without or with only very short styles, but with functional pollen (Fig. 7d, f). Female flowers have a larger ovary, but with non-functional pollen (Fig. $7 \mathrm{c}, \mathrm{e})$. This study demonstrates that A. tonkinensis and A. latifolia represent only a single species. 


\section{Is Actinidia indochinensis Merr. a distinct species or is it a variety of $A$. callosa Lindl.?}

Merrill (1938) described A. indochinensis as having granular indumentum on its younger parts and the abaxial leaf surfaces, and related it to A. callosa, which was completely glabrous. Li (1952), however, considered A. indochinensis to be a variety of $A$. callosa, citing the same characters that Merrill had used to justify the rank of species for this taxon (see also Hô, 1999; Bân, 2003). Liang (1984), on the other hand, concluded that $A$. indochinensis was completely different from A. callosa and its varieties. In this study, only 4 collections of $A$. indochinensis with flowers and 5 with fruits were available for inclusion.

Analyses of variation - In bivariate analyses, all the pairwise combinations of characters from flowering and fruiting specimens showed substantial overlap among the two taxa. In the PCA of specimens with fruit (Fig. 8), $42.4 \%$ of the total variation is accounted for by the first axis, with lamina length and fruit width (a negative value) being particularly important. The second axis accounted for $19.4 \%$ of the total variance, with major contributions coming from fruit length and apex length (a negative

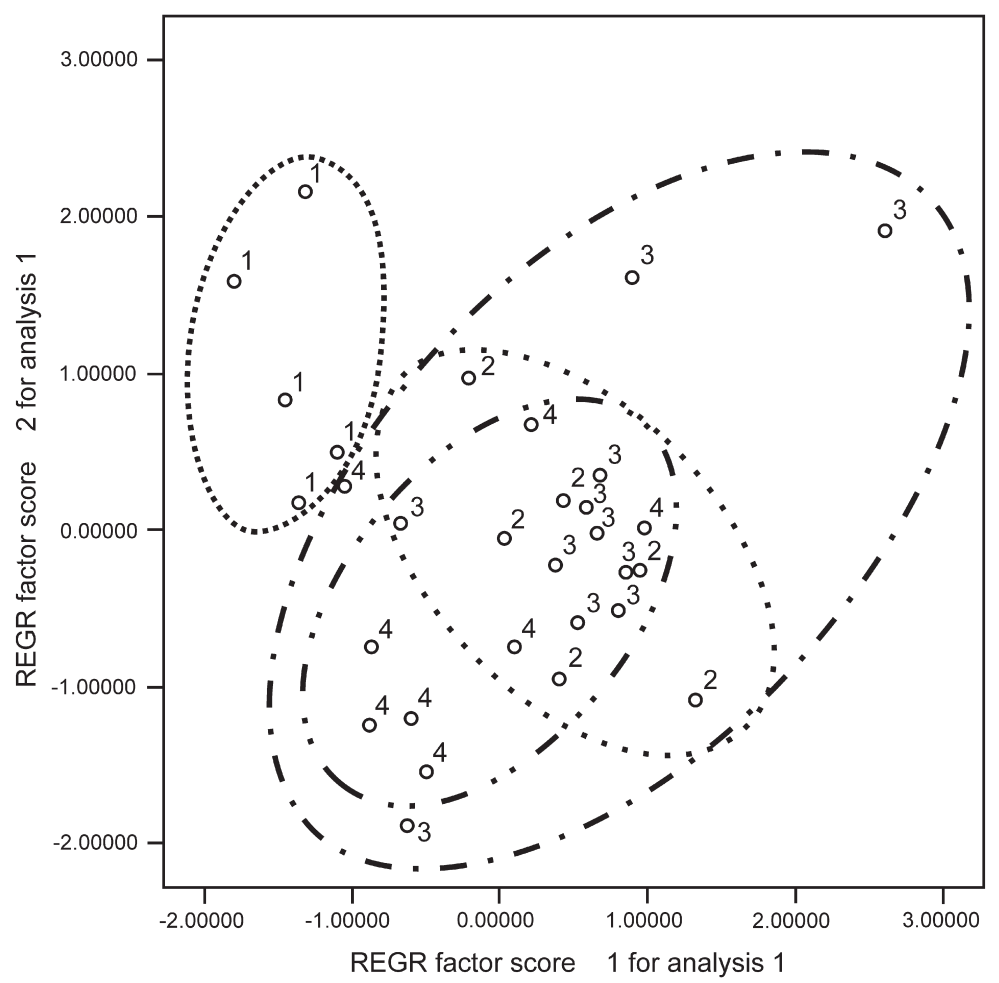

Fig. 8. PCA - two-dimensional scatter plots of Actinidia indochinensis Merr. and A. callosa Lindl. complex. Fruiting specimens: (1) A. indochinensis Merr.; (2) A. callosa Lindl. var. callosa; (3) A. callosa Lindl. var. henryi Maxim.; and (4) A. callosa Lindl. var. discolor C.F. Liang. 


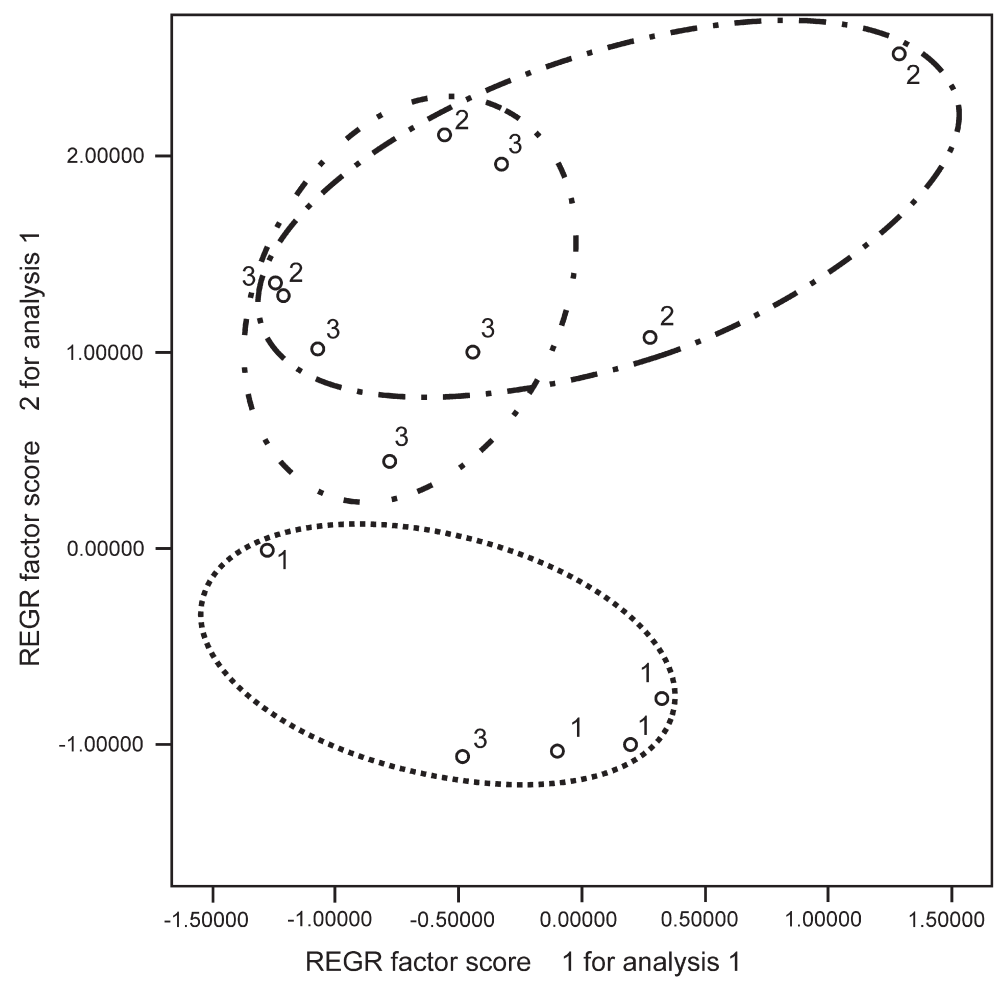

Fig. 9. PCA - two-dimensional scatter plots of Actinidia indochinensis Merr. and A. callosa Lindl. complex. Flowering specimens: (1) A. indochinensis Merr.; (2) A. callosa Lindl. var. callosa; and (3) A. callosa Lindl. var. discolor C.F. Liang.

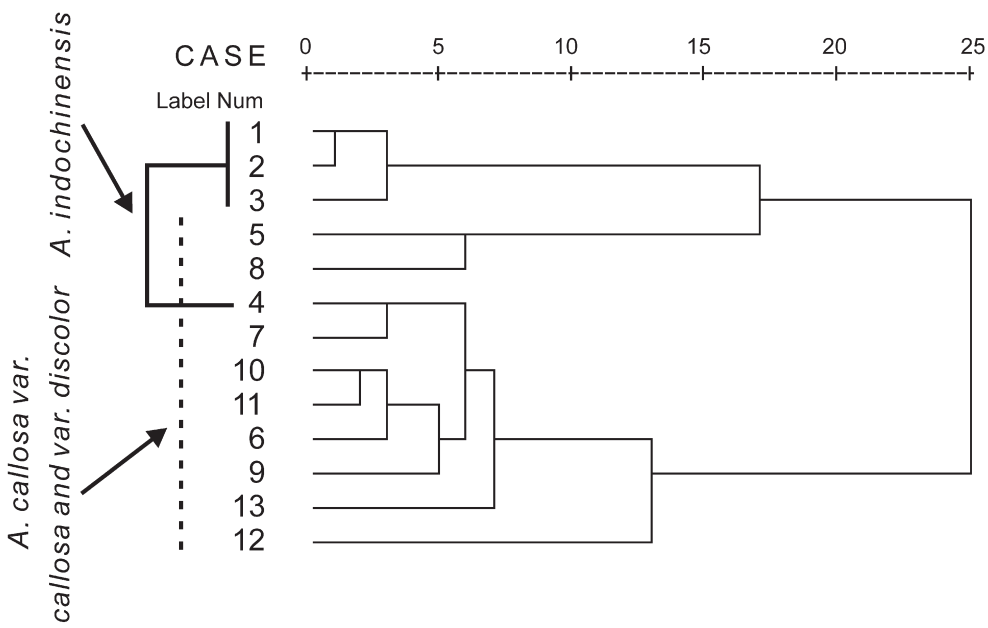

Fig. 10. Dendrogram of Actinidia indochinensis Merr., A. callosa Lindl. and its varieties. Flowering specimens: (1-4) A. indochinensis Merr.; (5-8) A. callosa Lindl. var. callosa; and (9-13) A. callosa Lindl. var. discolor C.F. Liang. 
value). Specimens of A. indochinensis formed a coherent group adjacent to the group of specimens identified as A. callosa, the latter formed a single, composite group. In the PCA of specimens with flower (Fig. 9), the first axis accounted for 57\% of the total variation, with major contributions coming from petal length and anther length (a negative value). The second axis accounted for $24.7 \%$ of the total variation, with major contributions from anther length and style length (a negative value). The overall pattern was similar to that of the preceding analysis, although there were perhaps too few specimens to draw too much in the way of the conclusion. Cluster dendrograms (Fig. $10,11)$ showed that specimens of A. indochinensis were mixed up with those of A. callos $a$ and its varieties.

Discussion - The results of the bivariate analyses show that many characters are correlated statistically but show a variable amount of overlap. The result of the PCA of both flowering and fruiting material show that specimens of A. indochinensis are barely

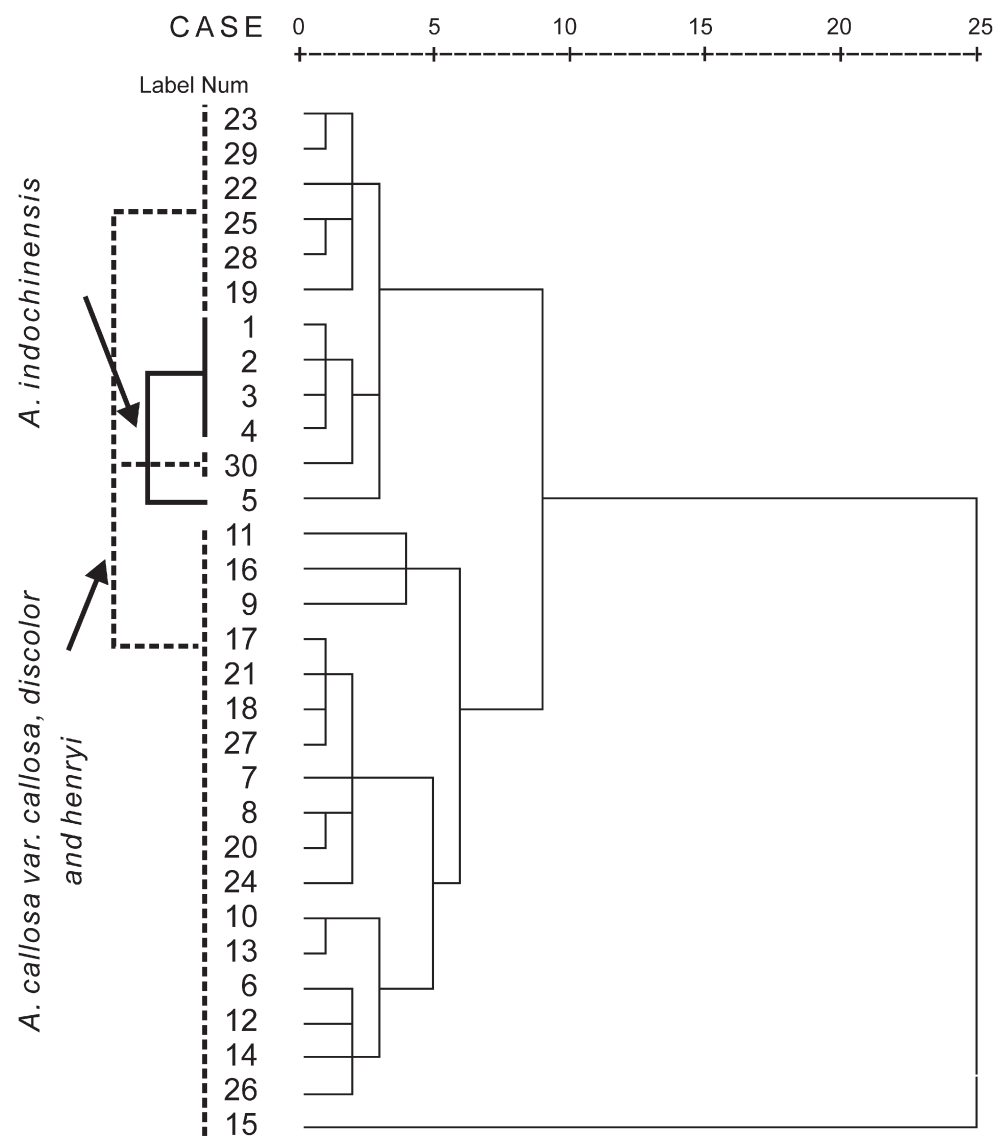

Fig. 11. Dendrogram of Actinidia indochinensis Merr., A. callosa Lindl. and its varieties. Fruiting specimens: (1-5) A. indochinensis Merr.; (6-11) A. callosa Lindl. var. callosa; (12-22) A. callosa Lindl. var. henryi Maxim.; and (23-30) A. callosa Lindl. var. discolor C.F. Liang. 
separable from those of $A$. callosa and its varieties (Fig. 8, 9). In the cluster analysis of flowering specimens, only a single specimen of $A$. indochinensis fall within the range of specimens of $A$. callosa and its varieties (Fig. 10), but in the larger analysis of fruiting specimens, a cluster of $A$. indochinensis specimens fall very close to those of A. callosa var. henryi Maxim. (Fig. 11). On the other hand, young branches and lamina of $A$. indochinensis are slightly puberulent and have granular reddish spots, quite unlike the glabrous branches and lamina of $A$. callosa and its varieties; these characters are not included in the quantitative morphological analyses. This result suggests that A. indochinensis is distinct from A. callosa and its varieties.

In a molecular analysis ( $\mathrm{Li}$ et al., 2002), A. indochinensis and specimens of two varieties of $A$. callosa appear together as a monophyletic group, or as a paraphyletic group in which other varieties of A. callosa and other species of Actinidia are embedded. This and our results clearly point to the fact that problems still need to be resolved in the taxonomic delimitation among these taxa.

\section{Implications for future work}

This study is a first step in an attempt to resolve taxonomic problems among species of Actinidiaceae in Vietnam. The multivariate analyses we employed greatly help to visualize the variation patterns in Vietnamese species of Saurauia and Actinidia. Such approaches are essential and are an integral component in critical morphological taxonomic studies, although, in the present study, the small number of specimens available for the measurements and analyses of the variation patterns, for a number of species, may have some influence on the results of our study. Such limitations, however, need to be resolved in future work, in which approaches such as molecular analysis need to be employed. Actinidiaceae are poorly known worldwide, and future studies will have to address problems at a broader geographical scale.

\section{TAXONOMIC TREATMENT}

\section{ACTINIDIACEAE}

Actinidiaceae Gilg \& Werderm. (1925) 36. — Type: Actindia Lindl. — Fam. cons., ICBN 2006.

Trees, shrubs or woody vines, indumentum varies, often of multicellular branched and unbranched trichomes. Leaves simple, petiolate, spirally arranged, exstipulate; lamina usually pubescent, margins serrate or serrulate, lateral veins in pairs and ascending, tertiary veins scalariform. Inflorescences cymose or thyrso-paniculate, axillary or flowers solitary. Plant dioecious or functionally dioecious with perfect flowers or rarely monoecious (flowers bisexual in Clematoclethra). Flowers actinomorphic, bracteate, sepals normally 5 , shorter than petals, persistent; petals normally 5, usually white; stamens numerous with filiform filaments, anthers dorsifixed, extrorse; gynoecium syncarpous, ovary superior, normally of 5 or numerous locules; styles distinct or basally connate. Fruits berries or, in Clematoclethra and some Saurauia, loculicidal capsules, globose to ovoid to oblong-ellipsoid; seeds numerous, reticulo-areolate, embedded in a mucilaginous pulp; embryo large, with copious endosperm. 


\section{KEY TO GENERA OCCURRING IN VIETNAM}

1a. Woody vine; flowers with free stamens and longitudinally dehiscent anthers; ovary many-loculed; fruit a berry that does not split open . . . . . . . 1. Actinidia

b. Tree or shrub; flowers with stamens basally adnate to petals and poricidally dehiscent anthers; ovary normally 3- or 5-loculed; fruit a berry that may split open loculicidally

2. Saurauia

\section{ACTINIDIA}

Actinidia Lindl. (1836) 439; Dunn (1911) 394; H.L. Li (1952) 1. - Type: Actinidia callosa Lindl.

Woody vines. Plants dioecious. Inflorescences axillary, cymose, or flowers solitary. Sepals ( 3 or 4 or) 5 ; petals (4 or) 5; filaments connate at base, pubescent, anthers with longitudinal dehiscence; ovary tomentose, carpels numerous. Fruits with lenticels or not.

\section{KEY TO SPECIES OCCURRING IN VIETNAM}

1a. Floral branchlets pubescent, especially the young parts, often densely so . . . . 2

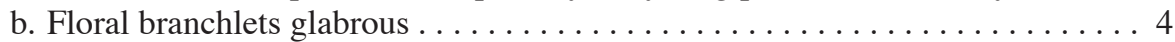

2a. Lamina base rounded to cordate; sepals densely tomentose . . . . . . . . 3

b. Lamina base acute; sepals glabrous . . . . . . . . 4. A. indochinensis

3a. Lower surface of lamina scattered setose along main veins . . . . 6. A. petelotii

b. Lower surface of lamina densely stellate . . . . . . . . . 3. A. fulvicoma

4a. Lamina base \pm acute to cuneate $\ldots \ldots \ldots \ldots \ldots \ldots \ldots \ldots \ldots \ldots$

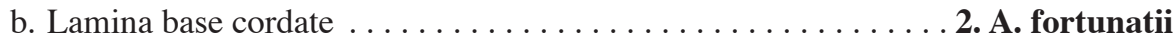

5a. Lamina ovate to obovate or broadly elliptic, c. two times longer than broad . . 6

b. Lamina narrowly elliptic to narrowly obovate, c. 3 times longer than broad ..... $\ldots \ldots \ldots \ldots \ldots \ldots \ldots \ldots \ldots \ldots \ldots \ldots \ldots \ldots \ldots \ldots$. rubricaulis

6a. Lower surface of lamina stellate-pubescent, flowers yellowish . . 5. A. latifolia

b. Lower surface of lamina glabrous except for barbate vein axils, flowers white...

1. A. callosa

1. Actinidia callosa Lindl. (1839) 439.

Actinidia callosa Lindl. var. discolor C.F. Liang - Fig. 12

Actinidia callosa Lindley var. discolor C.F. Liang (1984) 315. - Type: Li Zhong-ti 603855 (holo IBK n.v.), China, He-xian, 500 m, 11 Oct. 1959.

Woody vines. Branchlets glabrous. Petioles purple, 2.5-7 cm long, glabrous. Lamina chartaceous, maturing coriaceous, obovate or broadly elliptic, 5.5-11 by $3.5-5.5$ $\mathrm{cm}$, glabrous, adaxially blackish, abaxially brownish green, apex abruptly or shortly acuminate, acumen $0.5-1.5 \mathrm{~cm}$ long, base cuneate, lateral veins $6-8$ pairs. Inflorescences glabrous, 2-4-flowered or flowers solitary; peduncles $0.5-1.2 \mathrm{~cm}$ long; bracts subulate, $1-2 \mathrm{~mm}$; pedicels $0.5-1.65 \mathrm{~cm}$ long. Flowers white; sepals 5, ovate, 3.5-4.5 by $1.8-2.5 \mathrm{~mm}$, glabrous; petals 5 , obovate, $5.5-8.5$ by $2.5-4.5 \mathrm{~mm}$; stamens $30-50$, 


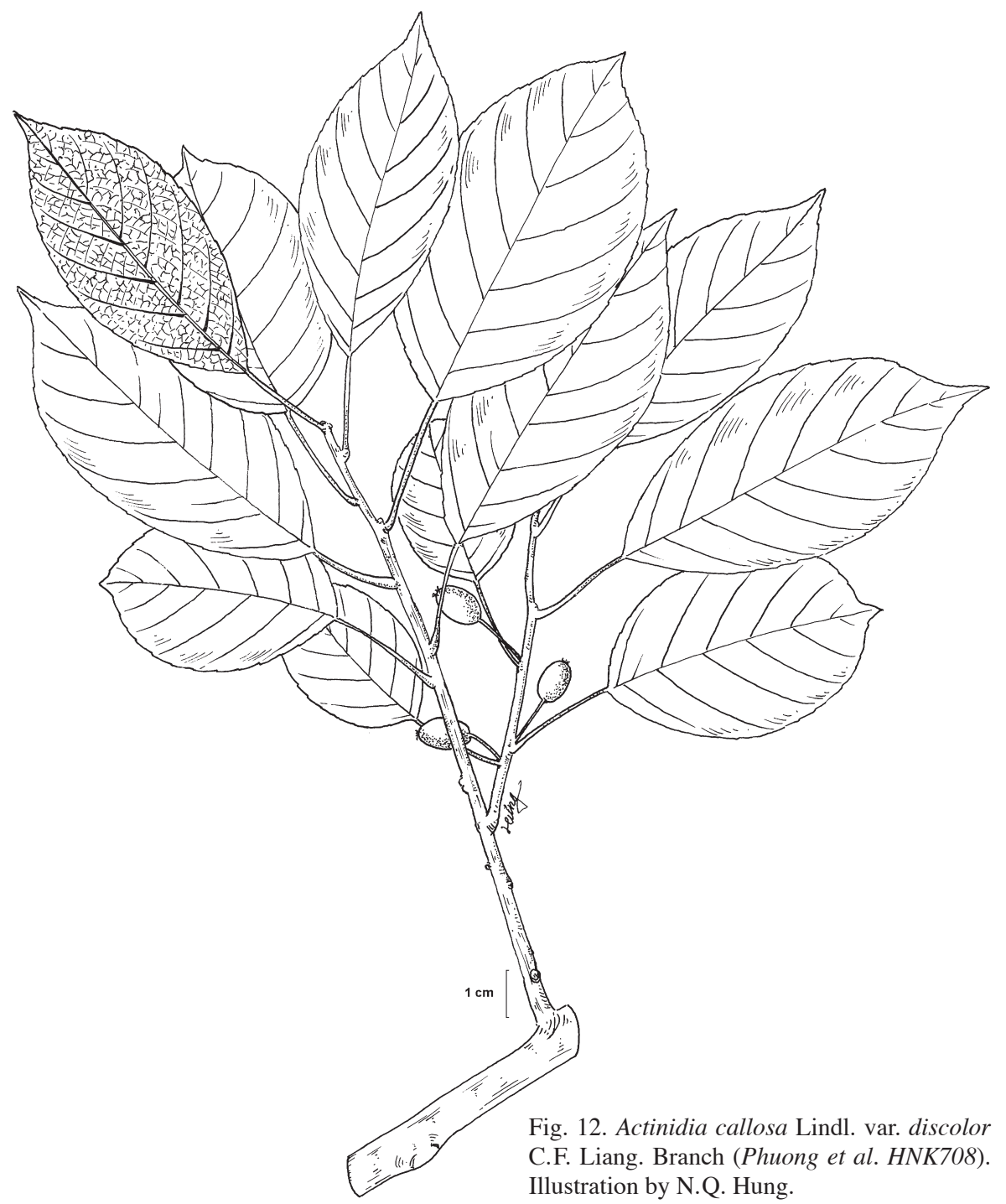

filaments $2.5-4 \mathrm{~mm}$ long, anthers $1.5-2 \mathrm{~mm}$ long; ovary ellipsoid, $1.5-2.2$ by $0.8-1.4$ $\mathrm{mm}$, brownish pubescent; styles (staminate flower) $0.4-0.6 \mathrm{~mm}$ long or (pistillate flower) 2-3 mm long. Fruits subglobose to oblong-ellipsoid, 1.5-3.5 cm long, glabrous when mature; calyx caducous.

Distribution - Mai Chau area in Vietnam. Also common in China (including Taiwan).

Habitat \& Ecology — Primary broad-leaved evergreen dry forest along tops of highly eroded remnant karst hills. Altitude 1100-1400 m. Flowering: April to May; fruiting: June to September. 
Note - The occurrence of A. callosa var. discolor in Vietnam represents a new record for the species in the country. The specimens (Phuong et al. HNK708, Hiep et al. 795) agree well with the Chinese specimens and with Liang's original description (Liang, 1984). Liang (1984) recognized seven varieties of A. callosa from China; these are distinguished, among others, by differences in leaf and fruit shape; these need reevaluation.

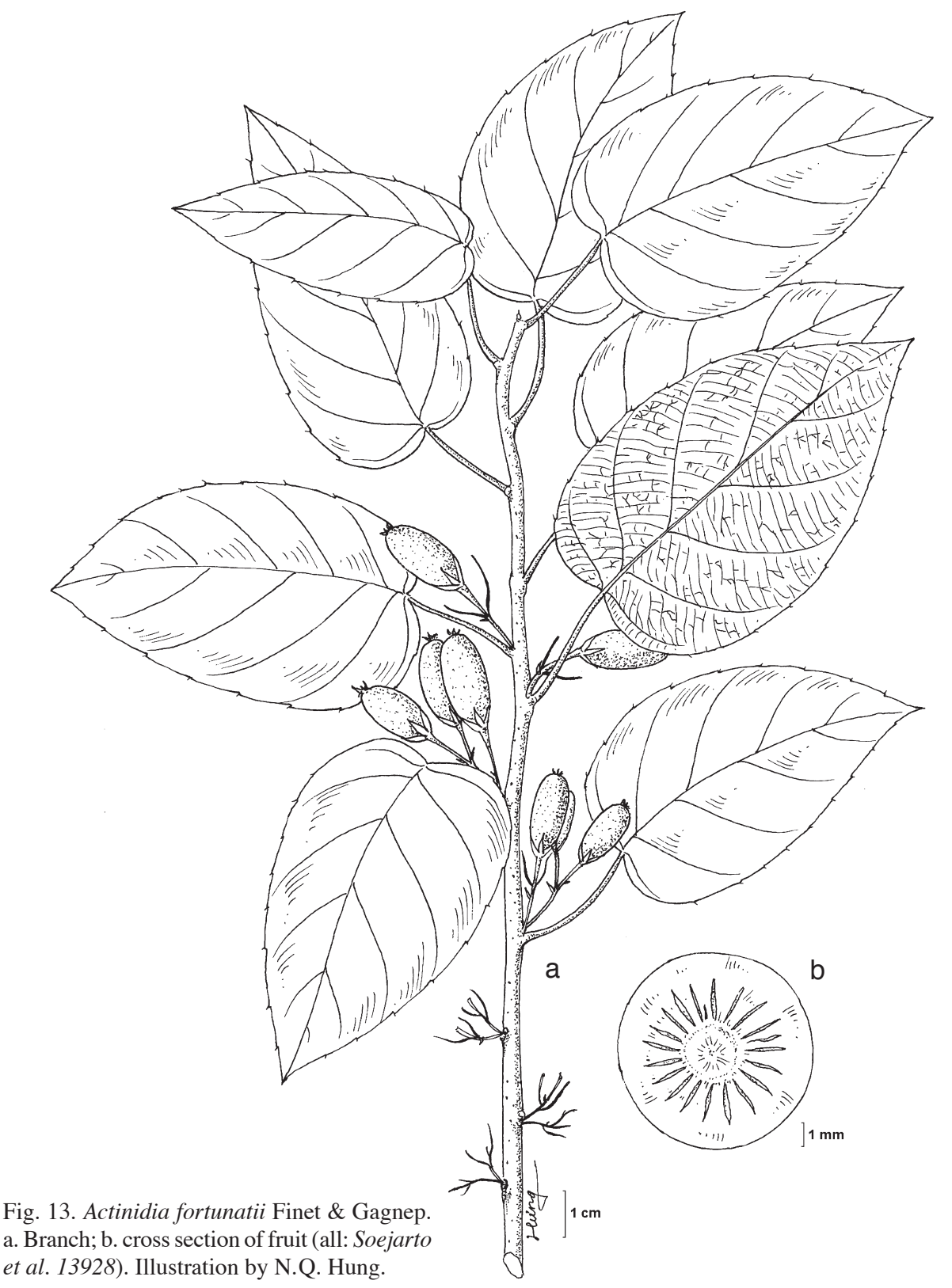


2. Actinidia fortunatii Finet \& Gagnep. - Fig. 13

Actinidia fortunatii Finet \& Gagnep. (1906a) 574. - Type: J. Cavalerie \& Fortunat 2350 (iso A), China, Guizhou, 8 June 1905.

Woody vines c. $5 \mathrm{~m}$, whole plant glabrous. Petioles purple, $1.5-3.5 \mathrm{~cm}$ long. Lamina chartaceous, broadly ovate to ovate-cordate, $6-12$ by $3.5-5 \mathrm{~cm}$, adaxially green, abaxially glaucous, apex acuminate, margins distantly serrulate, base cordate, lateral veins 5-7 pairs. Inflorescences $1-3$-flowered; peduncles $0.3-1.2 \mathrm{~cm}$ long; bracts subulate, 2-3 mm long; pedicels $0.5-1 \mathrm{~cm}$ long. Flowers reddish; sepals 5, ovate, $3-4.5$ by $2.5-3.5 \mathrm{~mm}$; petals 5 , obovate, $4-6$ by $3-4 \mathrm{~mm}$; stamens $35-60$, filaments $2-3.5$ mm long, anthers $1-1.2 \mathrm{~mm}$ long; ovary ovoid, $1.5-2$ by $2.5-3 \mathrm{~mm}$; styles $1.8-2 \mathrm{~mm}$ long. Fruits ellipsoid, 1-2 cm long; calyx persistent.

Distribution - Tam Dao National Park in Vietnam. Also common in China.

Habitat \& Ecology - Mountain slopes in tropical monsoon rain forest. Altitude c. 1000 m. Flowering: March to May; fruiting: June.

Note - Actinidia fortunatii differs from the other Actinidia species currently known in Vietnam in having purple petioles, glabrous lamina with a cordate base, and a glaucous lower leaf surface.

\section{Actinidia fulvicoma Hance}

Actinidia fulvicoma Hance (1885) 321; Dunn (1911) 409; H.L. Li (1952) 57. - Type: Henry 22293 (holo n.v.), China, Lo-fau-shan, May 1883.

Actinidia fulvicoma Hance var. hirsuta Finet \& Gagnep. (1906b) 52 (Mém. 4) 18 - Type: Bodinier 2427 (holo n.v.), China, Kouy-tcheou, Yang-ya, 20 July 1898.

Woody vines 4-8 m. Branchlets reddish brown-tomentose to -hirsute. Petioles 1-4.5 $\mathrm{cm}$ long, densely reddish brown-tomentose to -hirsute. Lamina membranaceous, becoming coriaceous, ovate to broadly ovate to ovate-elliptic, $5-13$ by $2.5-5.5 \mathrm{~cm}$, apex acuminate, acumen $0.5-1.5 \mathrm{~cm}$ long, margins setose-serrulate, base rounded to cordate, adaxially scattered to densely tomentose along major veins, abaxially densely tomentose along major veins, stellate-pubescent along minor veins, lateral veins 6-9 pairs. Inflorescences 1-4-flowered, densely covered with reddish brown tomentum; peduncles $0.4-1.5 \mathrm{~cm}$ long; bracts subulate to linear, $1-3 \mathrm{~mm}$ long; pedicels $0.7-2$ $\mathrm{cm}$ long. Flowers white; sepals 5, ovate to obovate, $4-7.5$ by $2.5-3.75 \mathrm{~mm}$, abaxially densely reddish tomentose, adaxially glabrous; petals 5 , white, obovate to narrowly obovate, $4.5-12$ by $4-8 \mathrm{~mm}$; stamens $35-55$, filaments $2.5-4.5 \mathrm{~mm}$ long, anthers ovate, $1-1.5 \mathrm{~mm}$ long; ovary subglobose, $2.5-4.5$ by $1.2-2.5 \mathrm{~mm}$, densely tomentose; styles $2.5-4.5 \mathrm{~mm}$ long. Fruits ovoid to oblong-conoid, $1.5-2 \mathrm{~cm}$ long, tomentose, turning glabrescent; calyx persistent.

Distribution - Bach Ma National Park, in Kontum Province, and in Ha Giang Province (close to China) in Vietnam. Also in China.

Habitat \& Ecology - Primary evergreen broad-leaved monsoon forest on sandstone, gneiss and limestone slopes. Altitude 1100-1400 m. Flowering: March to June; fruiting: June to August.

Note - This is the first record of the occurrence of A. fulvicoma in Vietnam. Specimens of this species agree well with the original description of the species, including the description by Finet \& Gagnepain (1906b). Some specimens have been misidentified as 
A. petelotii. The species is characterized by its usually yellowish brown indumentum (tomentose to hirsute), consisting of branched (stellate) and unbranched trichomes on the abaxial surface of the leaf blade.

\section{KEY TO THE VARIETIES}

1a. Branchlets and petioles densely tomentose-pubescent, flowers with small petals, $4.5-6.5$ by $4-5 \mathrm{~mm} \ldots \ldots \ldots \ldots \ldots \ldots \ldots \ldots \ldots$. var. fulvicoma

b. Branchlets and petioles densely hirsute-pubescent, flowers with larger petals, 9-12 by $7-8 \mathrm{~mm} \ldots \ldots \ldots \ldots \ldots \ldots \ldots \ldots \ldots \ldots \ldots \ldots \ldots \ldots$ b. var. hirsuta

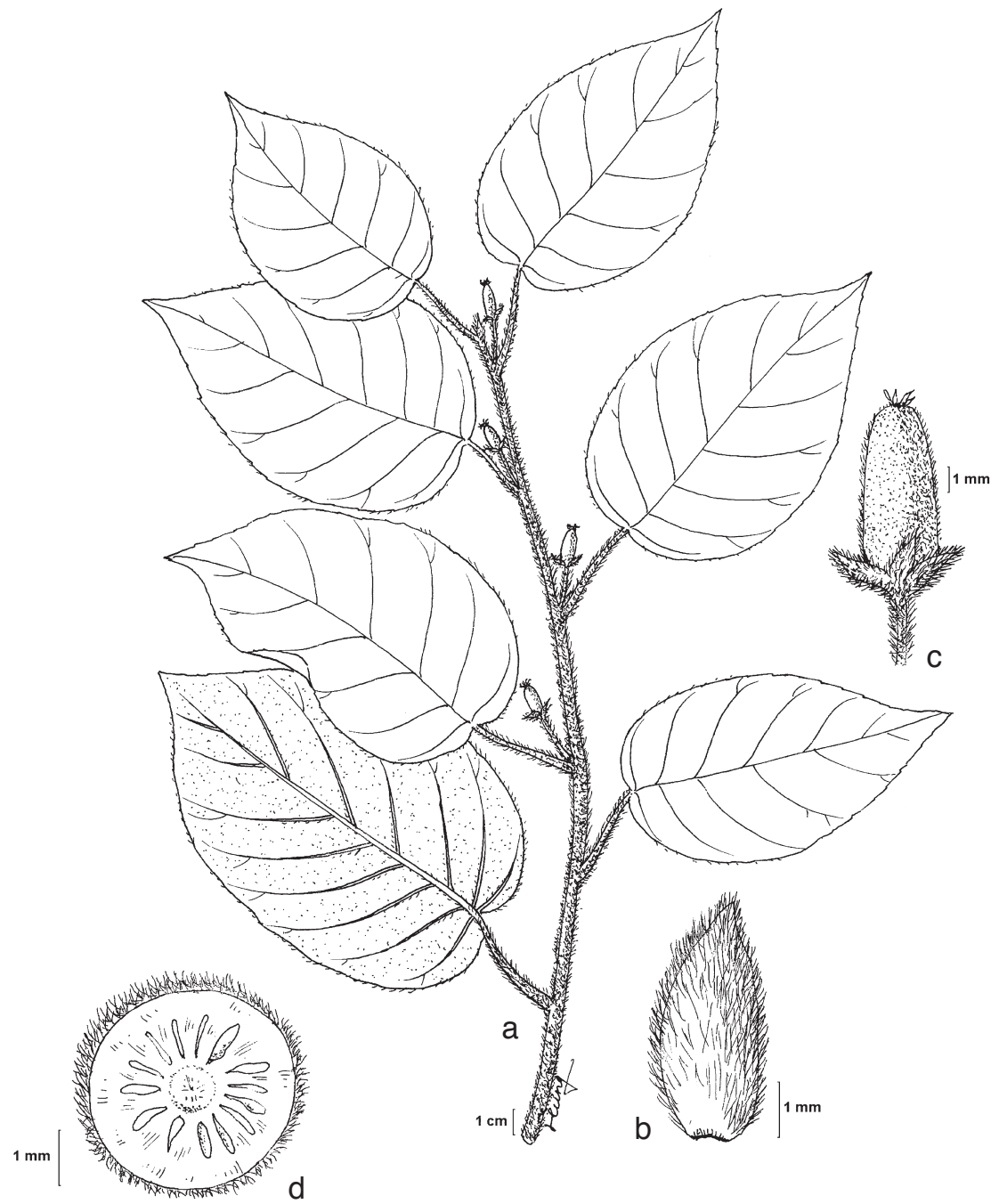

Fig. 14. Actinidia fulvicoma Hance var. hirsuta Finet \& Gagnep. a. Branch; b. bract; c. fruit; d. cross section of fruit (all: Dao 33). Illustration by N.Q. Hung. 


\section{a. var. fulvicoma}

Branchlets reddish brown tomentose. Leaf lamina ovate to narrowly ovate, $5-8$ by $2.5-$ $5.5 \mathrm{~cm}$, adaxially primary and secondary veins densely tomentose, abaxially densely long-stellate hairy on tertiary veins. Inflorescences $1-\geq 4$-flowered; peduncles $0.4-1 \mathrm{~cm}$ long; bracts subulate, $1-3 \mathrm{~mm}$ long; pedicels $0.7-2 \mathrm{~cm}$ long. Sepals obovate, $4-5.5$ by $2.5-3 \mathrm{~mm}$; petals obovate, $4.5-6.5$ by $4-5 \mathrm{~mm}$; filaments $2.5-4.5 \mathrm{~mm}$ long; anthers 1-1.2 mm long; ovary globose, $2.5-3$ by $1.2-2.5 \mathrm{~mm}$; styles $2.5-4 \mathrm{~mm}$ long.

Distribution - Bach Ma National Park, in Kontum Province.

Habitat \& Ecology - Limestone mountains in primary evergreen broad-leaved highland forest. Altitude 1100-1350 m.

b. var. hirsuta Finet \& Gagnep. - Fig. 14

Branchlets densely hirsute pubescent. Leaf lamina ovate to broadly ovate, 6.5-13 by $4.2-9.5 \mathrm{~cm}$, adaxially scattered tomentose throughout, abaxially densely stellate hairy on tertiary veins. Inflorescences $1-\geq 3$-flowered or flower solitary; peduncles $0.5-1.5$ cm long; bracts linear, 1-2 mm long; pedicels 1-1.5 cm long. Sepals ovate, 5.5-7.5 by $2.5-3.75 \mathrm{~mm}$; petals obovate, $9-12$ by $7-8 \mathrm{~mm}$; filaments $3-4.5 \mathrm{~mm}$ long; anthers 1.3-1.5 mm long; ovary globose to subglobose, 3.5-4.5 mm long; styles 4-4.5 mm long.

Distribution - Ha Giang Province (close to China) in Vietnam. Also in China (Tung Kay Shan).

Habitat \& Ecology - Close to China on hill in subtropical monsoon forest. Altitude up to $1000 \mathrm{~m}$.

\section{Actinidia indochinensis Merr. - Fig. 15}

Actinidia indochinensis Merr. (1938) 53; C.F. Liang (1984) 236. - Actinidia callosa Lindl. var. indochinensis (Merr.) H.L. Li (1952) 48; Hô (1999) 408, f. 1640; Bân (2003) 433. - Type: Petelot 5938 (holo A; iso NY, P, US), Vietnam, Lao Cai, Sapa, April 1936.

Woody vines c. $5 \mathrm{~m}$. Branchlets brownish purple, slightly puberulent, with scurfy reddish spots and white lenticels. Petioles pale yellow, 1.3-2.5 cm long. Lamina chartaceous, becoming coriaceous, elliptic to elliptic-obovate, $4.5-8.5$ by $2.5-5.4 \mathrm{~cm}$, apex shortly acuminate, margins finely serrulate, base cuneate, adaxially green, glabrous, abaxially with scattered red spots, puberulent, lateral veins 5-7 pairs. Inflorescences 3-5-flowered, or flowers solitary, covered by scattered glandular red dots and short hairs; peduncles $0.5-1 \mathrm{~cm}$ long; bracts linear, $0.5-1 \mathrm{~mm}$ long; pedicels $0.4-1 \mathrm{~cm}$ long. Flowers white; sepals 5, ovate, $4-6$ by $3-4 \mathrm{~mm}$, scattered puberulent; petals 5 , obovate, $7.5-11$ by $4-6.5 \mathrm{~mm}$, glabrous; stamens $40-65$, filaments $2.5-3.3 \mathrm{~mm}$ long, anthers 1.3-1.5 mm long; ovary globose, densely tomentose, styles 3-4 mm long. Fruits subglobose to oblong-ellipsoid; calyx caducous.

Distribution - Lao Cai-Sapa area in Vietnam. Also in China.

Habitat \& Ecology - Steep mountain slopes in tropical monsoon rain forest. Altitude 1600-2000 m. Flowering: March to April; fruiting: May to November. 


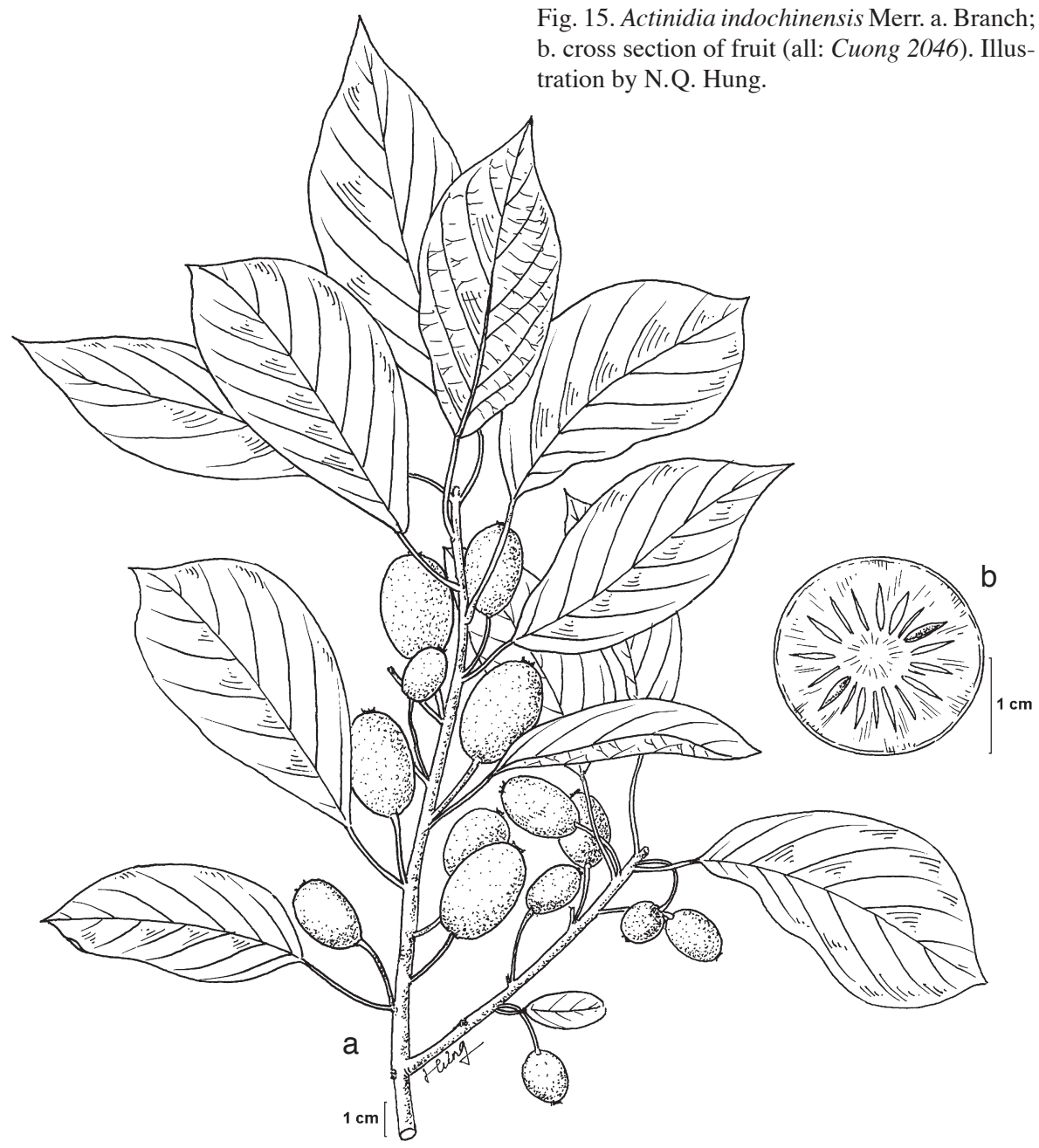

5. Actinidia latifolia (Gardner \& Champ.) Merr. - Fig. 16

Actinidia latifolia (Gardner \& Champ.) Merr. (1922) 330; H.L. Li (1952) 50; C.F. Liang (1984) 255; Hô (1999) 408, f. 1642; Bân (2003) 434. - Heptaca latifolia Gardner \& Champ. in Hooker (1849) 243. - Actinidia championi Benth. (1861) 26. - Type: J.G. Champion s.n. (holo n.v.), China (including Hong Kong).

Actinidia tonkinensis H.L. Li (1943) 366; Hô (1999) 409, f. 1644; Bân (2003) 434. - Type: Tsang 29907 (holo A; iso K, P), Quang Ninh, Lung Wan, Dan-ha, May 18-July 5, 1940.

Woody vines to 5-9 m. Branchlets glabrous with lenticels. Petioles $1.5-7 \mathrm{~cm}$ long, glabrous or with short stellate hairs. Lamina chartaceous, ovate to broadly ovate, $8-13$ by $5-10 \mathrm{~cm}$, apex acute to short-acuminate, margins minutely and remotely callose-serrulate, base broadly cuneate to rounded, adaxially glabrous, abaxially with short stellate hairs, lateral veins 6 or 7 pairs. Inflorescences $8-15$-flowered, brownish 


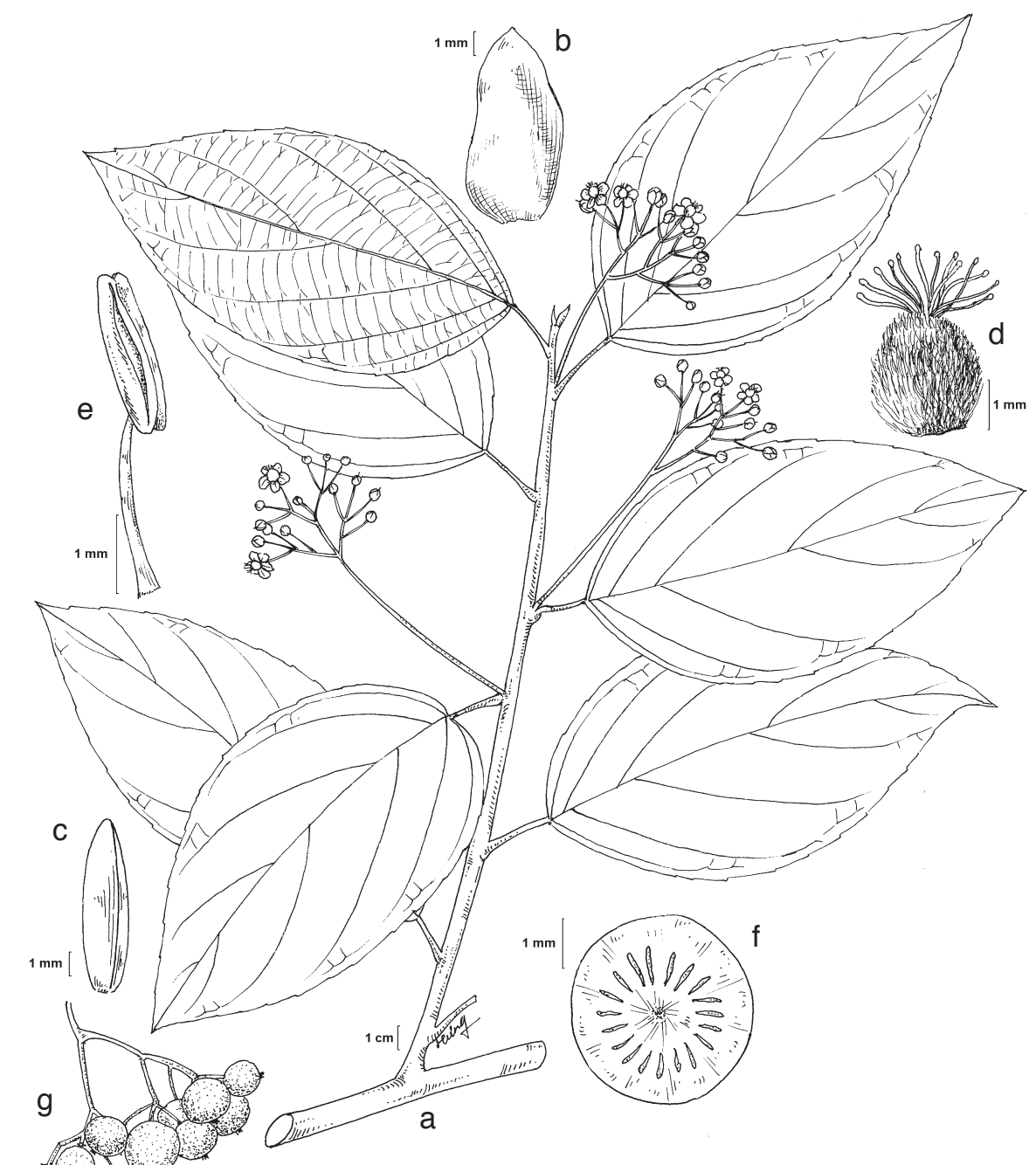

Fig. 16. Actinidia latifolia (Gardner \& Champ.) Merr. a. Branch with inflorescence; b. petal; c. sepal; d. gynoecium; e. stamens; f. staminate flower; g. fruits (a-f: Cuong 2050; g: Cuong 2048). Illustration by N.Q. Hung.

puberulent; peduncles 2-8 cm long; bracts linear, 1-2 mm long; pedicels $0.5-1.5 \mathrm{~cm}$ long. Flowers yellowish; sepals 5 , ovate, $4-5$ by $2-3 \mathrm{~mm}$, abaxially brownish tomentose, adaxially puberulent; petals 5 , elliptic to obovate, $6-8$ by $2.5-3.5 \mathrm{~mm}$; stamens 26-50, filaments $1.5-3.5 \mathrm{~mm}$ long, anthers $0.6-1 \mathrm{~mm}$ long; ovary globose, $1.5-2.5$ $\mathrm{mm}$ long, densely tomentose; styles $1.5-3 \mathrm{~mm}$ long (female flower), $0.3-0.5 \mathrm{~mm}$ long (staminate flower). Fruits globose to ovoid; calyx persistent.

Distribution - Vietnam. Also in Thailand, Cambodia, Laos, China (including Taiwan), Singapore, and Borneo. 
Habitat \& Ecology - Evergreen primary tropical and subtropical rain forests. Altitude 900-1800 m. Flowering: April to June; fruiting: July to November.

Note - The combination 'Actinidia latifolia var. indochinensis' made by Li (1952: 52) was an error. The basionym cited "Actinidia indochinensis Li (1943) 366" is erroneous since the reference cited ( $\mathrm{Li}, 1943: 366)$ is the place of publication of A.tonkinensis $\mathrm{Li}$; there is no "Actinidia indochinensis Li". Elsewhere in the same publication, Li synonymised $A$. indochinensis Merr. (with correct bibliographic citation) under $A$. callosa.

\section{Actinidia petelotii Diels}

Actinidia petelotii Diels (1931) 213; Gagnep. (1938) 28; Hô (1999) 409, f. 1643; Bân (2003) 434. - Type: Petelot 3829 (holo P; iso A, NY, US), Vietnam, Lao Cai, Sapa, Aug. 1930, fr.

Woody vines to 6-8 m. Branchlets covered by dense, reddish setose pubescence. Petioles reddish green, $1.5-2.5 \mathrm{~cm}$ long, also covered by dense, reddish green setose pubescence. Lamina ovate to narrowly ovate, $9-14$ by $6-9 \mathrm{~cm}$, apex acute to acuminate, acumen $0.75-1.5 \mathrm{~cm}$ long, margins finely serrulate, base cordate to subcordate or rounded, adaxially glabrous, abaxially scattered setose along main veins, lateral veins 6-8 pairs. Inflorescences cymose or flowers solitary, densely setose; peduncles $0.5-1.3 \mathrm{~cm}$ long; bracts linear, 2-3 mm long; pedicels 1-1.7 cm long. Flowers white; sepals 5 , ovate, $5-6$ by $2-3 \mathrm{~mm}$, abaxially setose; petals 5 , obovate, $6-7.5$ by $3.5-4.5$ $\mathrm{mm}$, glabrous; stamens 38-55, filaments $1-2.5 \mathrm{~mm}$ long, anthers ovate, $0.8-1 \mathrm{~mm}$ long; ovary ovoid, 1.5-2 mm long, styles tomentose, 0.7-1.2 mm long. Fruits ovoid to oblong-ovoid, $2-2.5$ by $0.6-0.8 \mathrm{~cm}$, scattered setose; calyx persistent.

Distribution - Lao Cai and Cao Bang areas in Vietnam.

Habitat \& Ecology - Granitic mountain slopes, primary evergreen broad-leaved forest on limestone formation. Altitude 1500-2000 m. Flowering: March to May; fruiting: June.

Note - Actinidia petelotii is clearly distinct from other Vietnamese Actinidia species in its densely reddish setose hairs on the young branches, petioles, and main and lateral veins; the lamina is ovate and reddish green when young.

\section{Actinidia rubricaulis Dunn - Fig. 17}

Actinidia rubricaulis Dunn (1906) 2. - Type: Henry 10696 (iso A, MO), China, Yunnan, Feng Chen Lin, Red river, alt. $7000 \mathrm{ft}$, n.a., fl.

Actinidia callosa Lindl. var. coriacea Finet \& Gagnep. (1906b) 52. - Actinidia coriacea (Finet \& Gagnep.) Dunn (1911) 405; Hô (1999) 408, f. 1641; Bân (2003) 434. - Type: M. Delavay 5152 (iso K), China, Yunnan, 1893, fl.

Woody vines to $10 \mathrm{~m}$. Branchlets reddish white, glabrous. Petioles reddish, 2-3 cm long, glabrous. Lamina chartaceous, elliptic to narrowly elliptic to obovate, turning coriaceous at maturity, $10-16$ by $3-5 \mathrm{~cm}$, glabrous, apex acuminate, $0.5-1 \mathrm{~cm}$ long, margins loosely serrulate, base cuneate, lateral veins 6-8 pairs. Inflorescences glabrous, 3-flowered or flower solitary; peduncles $0.5-1.3 \mathrm{~cm}$ long; bracts subulate, 1.5-2 mm; pedicels slender, reddish, 1.5-2 cm long. Flowers reddish; sepals 5, ovate, $4-5$ by $2-3.5 \mathrm{~mm}$, glabrous; petals 5 , whitish red, $7-10$ by $4-7 \mathrm{~mm}$; stamens $40-55$, filaments 3-4.5 mm long, anthers 1-1.5 mm long; ovary ovoid to oblong-ellipsoid, 


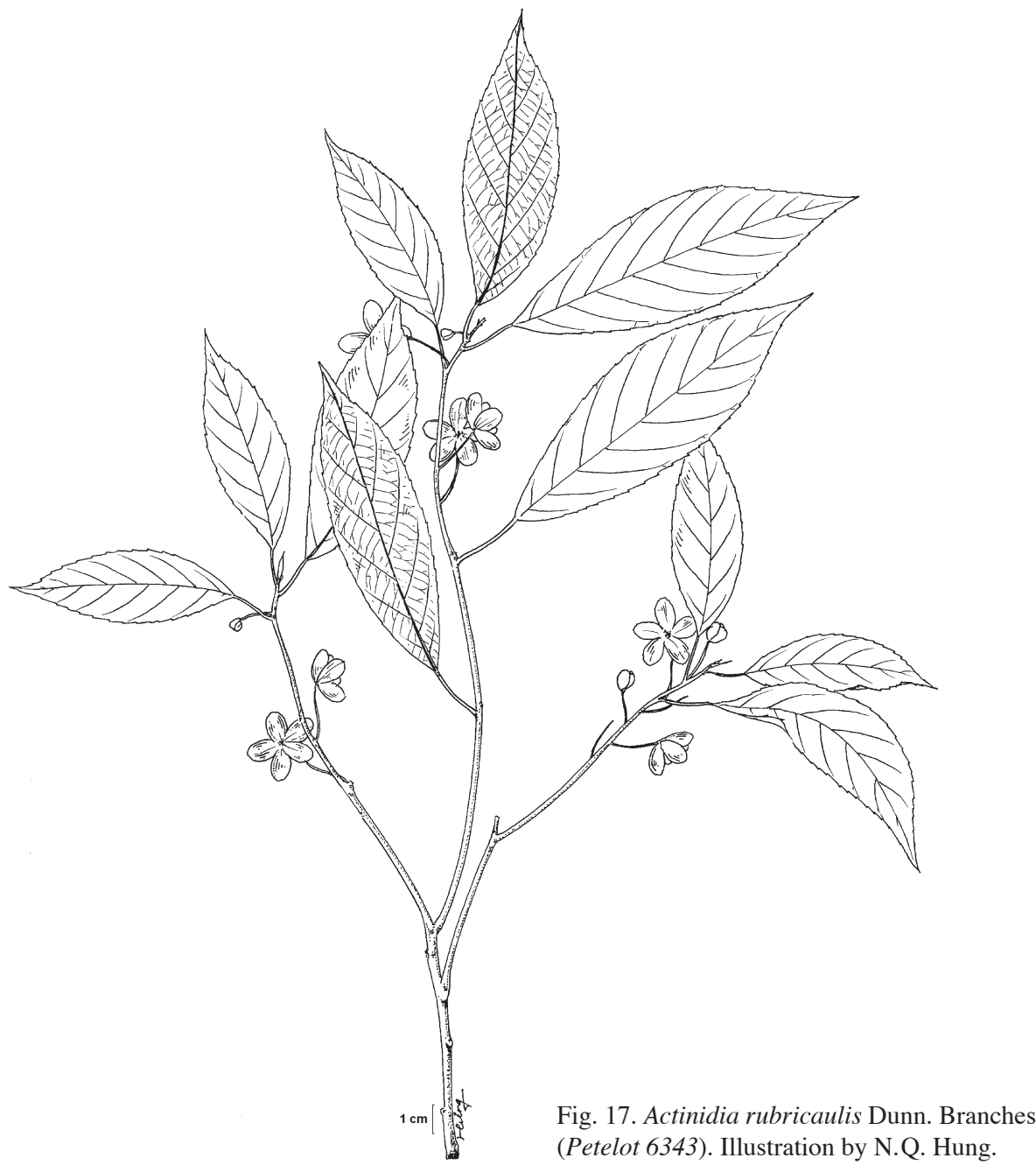

1.6-2.5 mm long, pubescent, styles $0.5-3 \mathrm{~mm}$ long. Fruits ovoid, glabrous at maturity; calyx persistent.

Distribution - Lao Cai-Sapa and Fan Si Pan Mountain areas in Vietnam. Also in China.

Habitat \& Ecology - Streamsides on limestone slopes in tropical monsoon rain forest. Altitude 1600-1700 m. Flowering: March to May; fruiting: June to September.

Note - Finet \& Gagnepain (1906b) described A. callosa var. coriacea, but Dunn (1911) thought that it was a separate species and compared it with A. rubricaulis. The former differs in having more thickly coriaceous leaves. However, the leaves of both taxa are glabrous and similar in shape and texture. The flowers are also similar in having densely tomentose ovaries. Here A. callosa var. coriacea $(=$ A. coriacea $)$ is relegated to synonymy under $A$. rubricaulis. 


\section{SAURAUIA}

Saurauia Willd. (1801) 407. - Type: Saurauia excelsa Willd. - Gen. cons., ICBN 2006.

Trees or shrubs. Branchlets and leaves mostly pubescent, trichomes of various types and sizes, forming a dense or sparse indument cover. Inflorescences normally crowded around tip of branchlets or spreading lower down the branchlets, ranging from short, dense and sessile cymose clusters of $1 \mathrm{~cm}$ to wide-spreading thyrso-paniculate clusters of $35 \mathrm{~cm}$ in length. Flowers bisexual, but functionally unisexual; calyx pubescent to glabrous, corolla glabrous; stamens numerous, filaments adnate to corolla at base, anthers seemingly poricidal; ovary globose, prominent or obsolete, normally glabrous, (3-)5loculed, styles prominent or obsolete. Fruits globose to ovoid berries that sometimes split open loculicidally, pulp mucilaginous, seeds numerous; calyx persistent.

\section{KEY TO SPECIES OCCURRING IN VIETNAM}

1a. Inflorescences short, up to $6 \mathrm{~cm}$ long, often forming dense clusters on the branchlets, sometimes trichotomous, flowers less than 20 per cluster . . . . . . . . 2

b. Inflorescences long and wide-spreading, $12-30 \mathrm{~cm}$ long, flowers $25-40$ per clus-

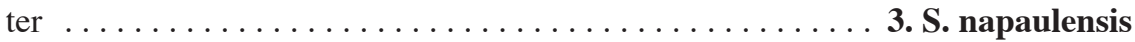

2a. Branchlets scattered pubescent, leaf lamina less than 2.5 times longer than wide;

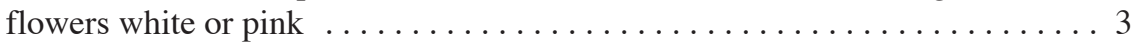

b. Branchlets abundantly and coarsely setose-pubescent, leaf lamina 3 or 4 times

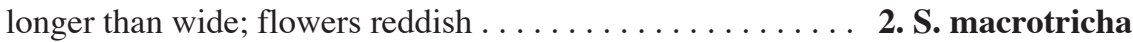

3a. Lower surface of lamina practically glabrous, with scattered strigose trichomes

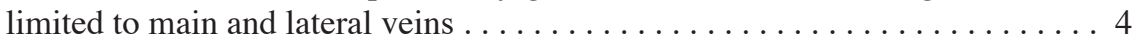

b. Lower surface of lamina covered by dense, brown to yellowish brown tomentum

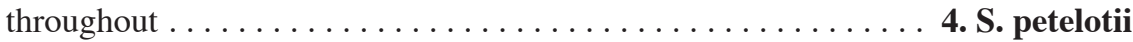

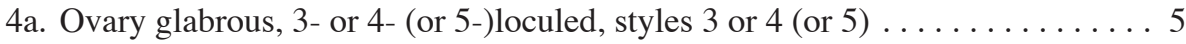

b. Ovary tomentose, 5 -loculed, styles $5 \ldots \ldots \ldots \ldots \ldots \ldots$. S. armata

5a. Peduncle 1-20 mm long; flowers $6.5-10$ by $5.5-8.5 \mathrm{~mm}$, styles $3,4.5-7 \mathrm{~mm}$, free to fused at base about one-third their length . . . . . . . . . tristyla

b. Peduncle 5-55 mm long; flowers $4.8-7.5$ by $4.5-5.5 \mathrm{~mm}$, styles 4 or $5,1.5-3.2$ $\mathrm{mm}$, connate at base more than half their length . . . . . 5. S. roxburghii

\section{Saurauia armata Kurz - Fig. 18}

Saurauia armata Kurz (1873) 59. - Type: Burma (K? n.v.).

Saurauia dillenioides Gagnep. (1938) 25. - Type: Poilane 25776 (iso P), M. Toung, Phong Saly, 500 m, 20 April 1936, fl.

Shrubs to treelets 3-5 m tall. Branchlets covered with scattered strigose indumentum. Petioles 2-3 cm long, scattered strigose. Lamina coriaceous, obovate to narrowly obovate, $20-45$ by $12-25 \mathrm{~cm}$, apex acute to shortly acuminate, acumen $0.4-0.5 \mathrm{~cm}$ long, margins entire at base, mucronulate-serrulate toward the apex, base cuneate, adaxially glabrous, abaxially scattered strigose along major veins, lateral veins 16-21 pairs. Inflorescences 1-2 cm long, 1-3-flowered, flowers sometimes solitary; peduncles subsessile to $1 \mathrm{~cm}$ long; bracts obovate, $6-8$ by $4-5 \mathrm{~mm}$, with scattered tomentose 


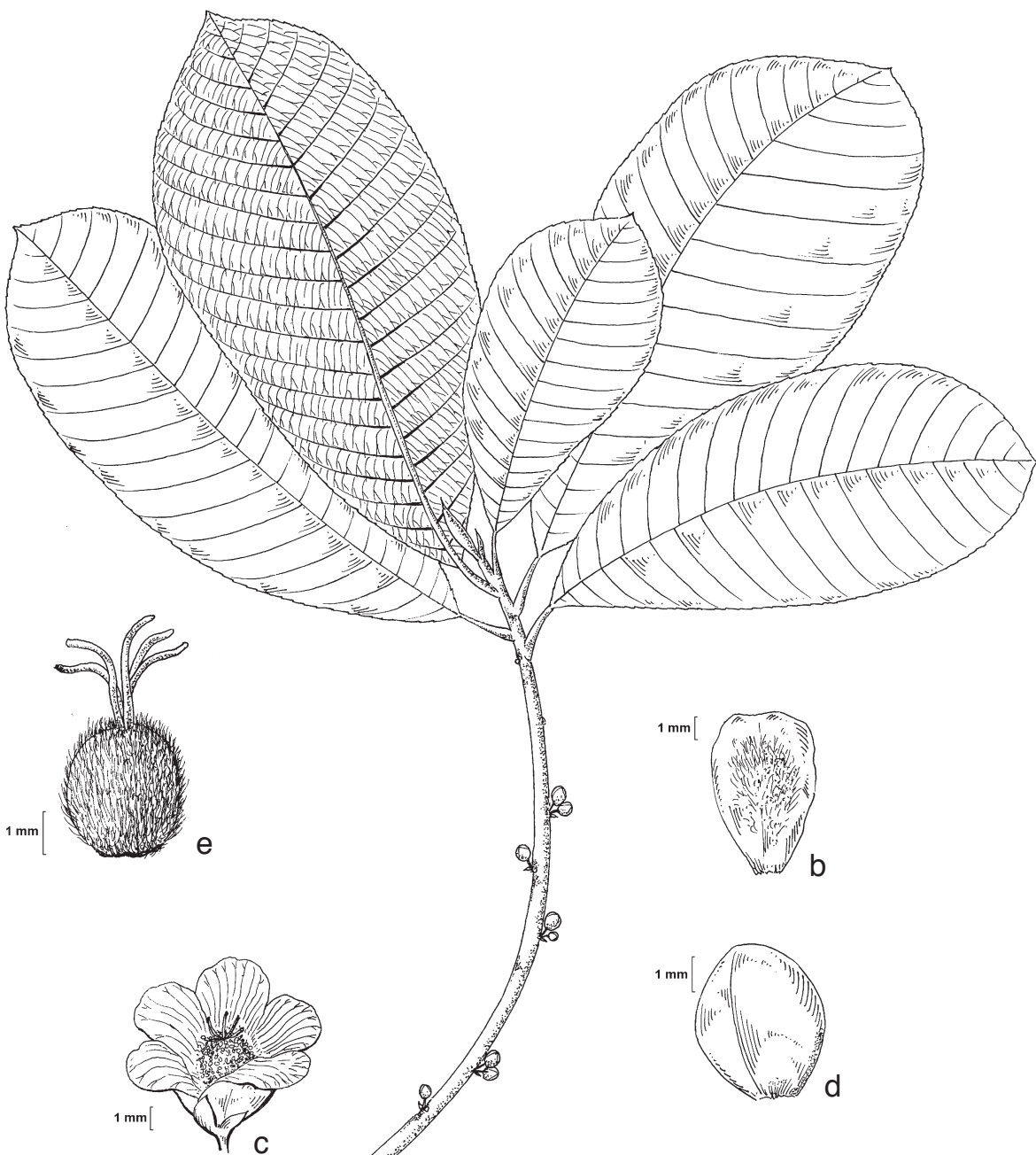

Fig. 18. Saurauia armata Kurz. a. Branch; b. bract; c. flower; d. sepal; e. gynoecium (all: Binh \& Cuong 1528). Illustration by N.Q. Hung.

indumentum; pedicels $0.7-1.5 \mathrm{~cm}$ long. Flowers white; sepals 5, ovate to suborbicular, puberulent, $7-10$ by $5-8 \mathrm{~mm}$; petals 5 , white, ovate, $10-15$ by $8-9 \mathrm{~mm}$; stamens $30-50$, filaments $1.5-2 \mathrm{~mm}$ long, anthers c. $2 \mathrm{~mm}$ long; ovary subglobose to ovoid-oblong, 5-loculed, densely tomentose; styles 5, 2-3.5 mm long, free almost throughout their length. Fruits tomentose-pubescent.

Distribution - Vietnam in Lai Chau and Dien Bien. Also in China.

Habitat \& Ecology - Limestone mountain slopes in tropical monsoon evergreen forest. Altitude 500-1200 m. Flowering: April to June; fruiting: dates not known. 


\section{Saurauia macrotricha Kurz - Fig. 19}

Saurauia macrotricha Kurz (1873) 60; Dyer in Hook.f. (1874) 287; C.F. Liang (1984) 301; Hô (1999) 410, f. 1647. - Type: Anderson 1287 (iso K), China, Yunnan, 2 April 1868, fr.

Treelets 4-5 m tall. Branchlets densely covered with reddish pubescence. Petioles 1-2 $\mathrm{cm}$, setose-pubescent. Lamina chartaceous, lanceolate to narrowly elliptic, $15-32$ by 5-10 cm, apex acuminate, acumen to $1-2.5 \mathrm{~cm}$ long, margins finely serrulate, base cuneate, adaxially covered with setose trichomes along main veins, abaxially the whole surface setose-pubescent, lateral veins $16-26$ pairs. Inflorescences $1.5-2 \mathrm{~cm}$ long,

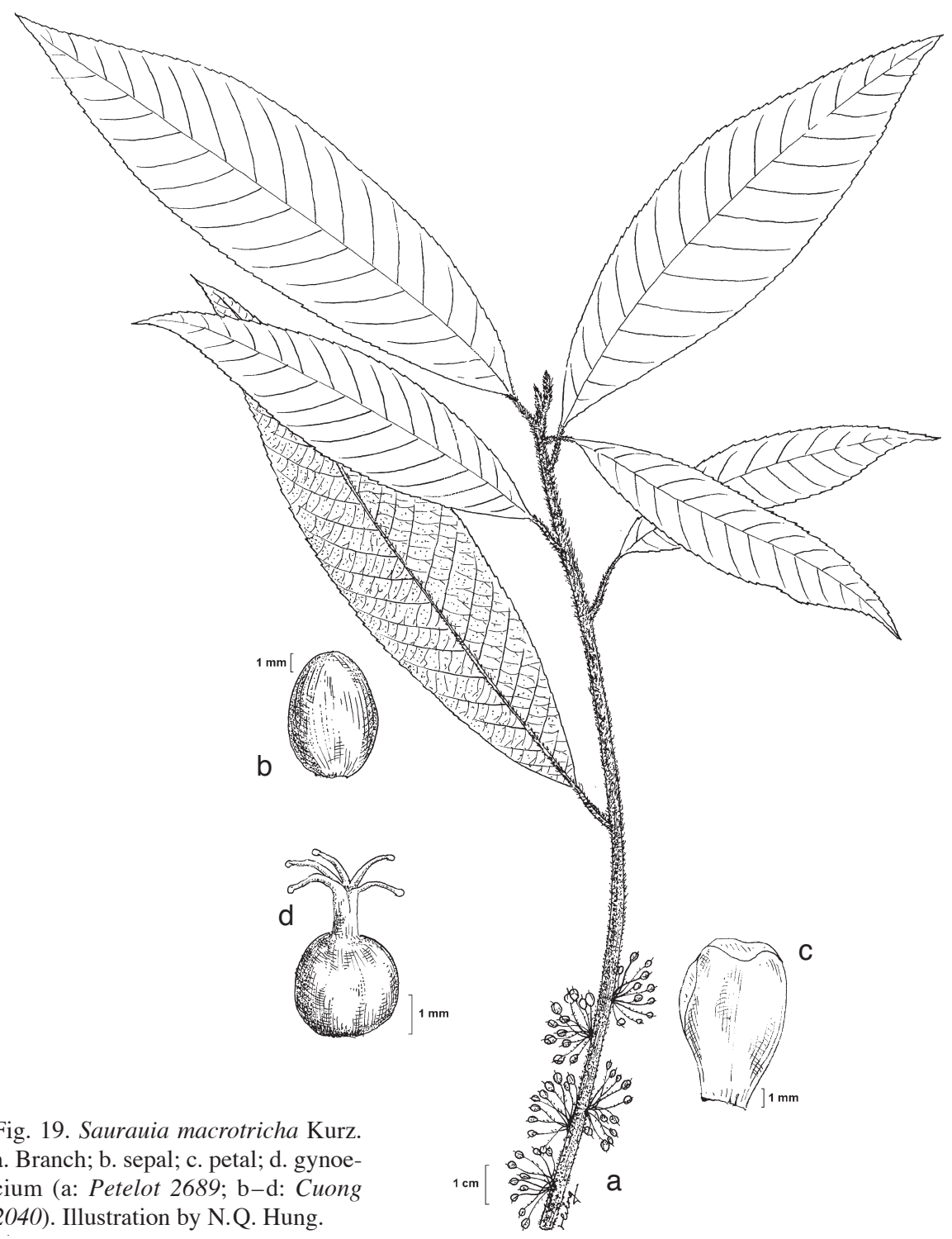


10-15-flowered; peduncles $0.3-0.5 \mathrm{~cm}$ long; bracts linear, 1-2 mm long; pedicels 0.8-2 cm long; peduncles, pedicels, and bracts setose-pubescent. Flowers reddish to red; sepals 5 , rounded-ovate to -elliptic, reddish, $5.5-8$ by $4-6.5 \mathrm{~mm}$, glabrous; petals 5 , obovate, reddish pink, $5-6.5$ by $4.5-6.5 \mathrm{~mm}$; stamens $39-43$, filaments $1.5-2.5$ $\mathrm{mm}$ long, anthers 1-1.5 mm long; ovary subglobose, 5-loculed, 3-4 by $2.5-4 \mathrm{~mm}$, glabrous; styles 5, 3.5-4 mm long, fused at base, free on the upper half. Fruits globose, glabrous.

Distribution - Lao Cai-Sapa area in Vietnam. Also in India, Myanmar, China, and Thailand.

Habitat \& Ecology - Along streamsides and on limestone mountain slopes in tropical monsoon rain forest. Altitude 1000-1728 m. Flowering: May to July; fruiting: dates not known.

Note - Saurauia macrotricha is distinct from other Vietnamese species in its densely setose branchlets, lanceolate to narrowly elliptic lamina, with the upper surface covered by scattered setose trichomes along the major veins, while the lower surface is densely setose throughout. Additionally, the flowers are red to reddish pink, on setose-pubescent inflorescences.

\section{Saurauia napaulensis DC.}

Saurauia napaulensis DC. (1822) 421; Wall. (1831) 77; Dyer in Hook.f. (1874) 286; Gagnep. (1938) 27; C.F. Liang (1984) 289; Hô (1999) 410, f. 1648; Bân (2003) 435. - Type: Wallich Cat. No. 14691 (iso NY).

Saurauia griffithii Dyer var. annamica Gagnep. (1938) 27. - Syntypes: Evrard 2192 (K, P), Dalat, 11 Dec. 1924, fl.; Poilane 16783 (P), Laos, 30 August 1929, fr.

Treelets 5-10 m tall. Branchlets densely strigose-pubescent on the younger parts. Petioles 2-4 cm long, strigose-pubescent. Lamina coriaceous, elliptic to narrowly elliptic, $15-25$ by $4-10 \mathrm{~cm}$, apex shortly acuminate, acumen $0.5-0.8 \mathrm{~cm}$ long, margins mucronulate-serrulate, base cuneate, adaxially covered by very fine stellate trichomes when young, becoming glabrescent to glabrous, abaxially covered by somewhat appressed arachnoid pubescence throughout when young, major veins also strigose-pubescent, lateral veins 16-25 pairs. Inflorescences lax and wide-spreading, (12-)25-35 cm long, 20-40-flowered; peduncles 9-16 cm long; bracts subulate to linear, 3-4 mm long; pedicels $1-2.5 \mathrm{~cm}$ long; peduncles, branches, pedicels, and bracts scurfy pubescent, bracts may become glabrescent. Flowers reddish-pink; sepals 5, rounded-ovate to -obovate, $6.5-7.5$ by $4.5-5.5 \mathrm{~mm}$, scattered puberulent outside, glabrous inside; petals 5 , obovate, $10-15$ by $5-7.5 \mathrm{~mm}$; stamens $30-60$, filaments $2.5-3.5 \mathrm{~mm}$ long, anthers $2-3 \mathrm{~mm}$ long; ovary subglobose, 5-loculed, $1.5-2$ by $1.3-1.7 \mathrm{~mm}$, glabrous; styles $5,0.8-1.2$ $\mathrm{mm}$ long, basally connate half of their length. Fruits globose and angled, glabrous.

Distribution - Lao Cai, Hoa Binh, Nha Trang, and Kon Tum Provinces in Vietnam. Also in India, Nepal, Bhutan, Myanmar, Thailand, Laos, Malaysia, and China.

Habitat \& Ecology - Along streamsides and on slopes in tropical monsoon rain forest. Altitude 500-1900 m. Flowering: May to July; fruiting: August to November.

Note - Saurauia napaulensis is clearly distinct and easily recognizable from other Vietnamese species in its long and wide-spreading, long-peduncled inflorescences, with a high number of flowers per inflorescence, dense brownish arachnoid pubescence on the lower surface of the lamina when young, and its reddish pink corolla. 


\section{Saurauia petelotii Merr. - Fig. 20}

Saurauia petelotii Merr. (1924) 426. - Type: Petelot 669 (holo UC n.v.; iso A, NY, P, US), Viet

Nam, Cao Bang, Pia Quac, 800 m, July 1922, fl., fr.

Treelets 4-8 m tall. Branchlets covered with brown scurfy pubescence, trichomes of strigose type. Petioles 2-6 cm long, scattered strigose to puberulent. Lamina coriaceous, ovate to obovate or elliptic-obovate, $12-29$ by $6.5-12.5 \mathrm{~cm}$, apex shortly acuminate, acumen $0.4-0.6 \mathrm{~cm}$ long, margins subentire at base, finely and laxly serrulate toward apex, base cuneate, adaxially blackish when dry, glabrous, abaxially densely tomentose-pubescent, lateral veins $20-25$ pairs. Inflorescences $2-4 \mathrm{~cm}$ long, 10-20flowered; peduncles to $0.8 \mathrm{~mm}$ long; bracts linear, $2-3 \mathrm{~mm}$ long; pedicels $0.8-1 \mathrm{~cm}$ long; peduncles, pedicels and bracts scurfy pubescent. Flowers pinkish white; sepals 5 , elliptic-ovate, $3-4$ by $2-3.5 \mathrm{~mm}$, glabrous; petals obovate, $4.5-5.3$ by $2-4 \mathrm{~mm}$; stamens $40-55$, filaments $1-5 \mathrm{~mm}$ long, anthers $0.6-1.2 \mathrm{~mm}$ long; ovary subglobose,

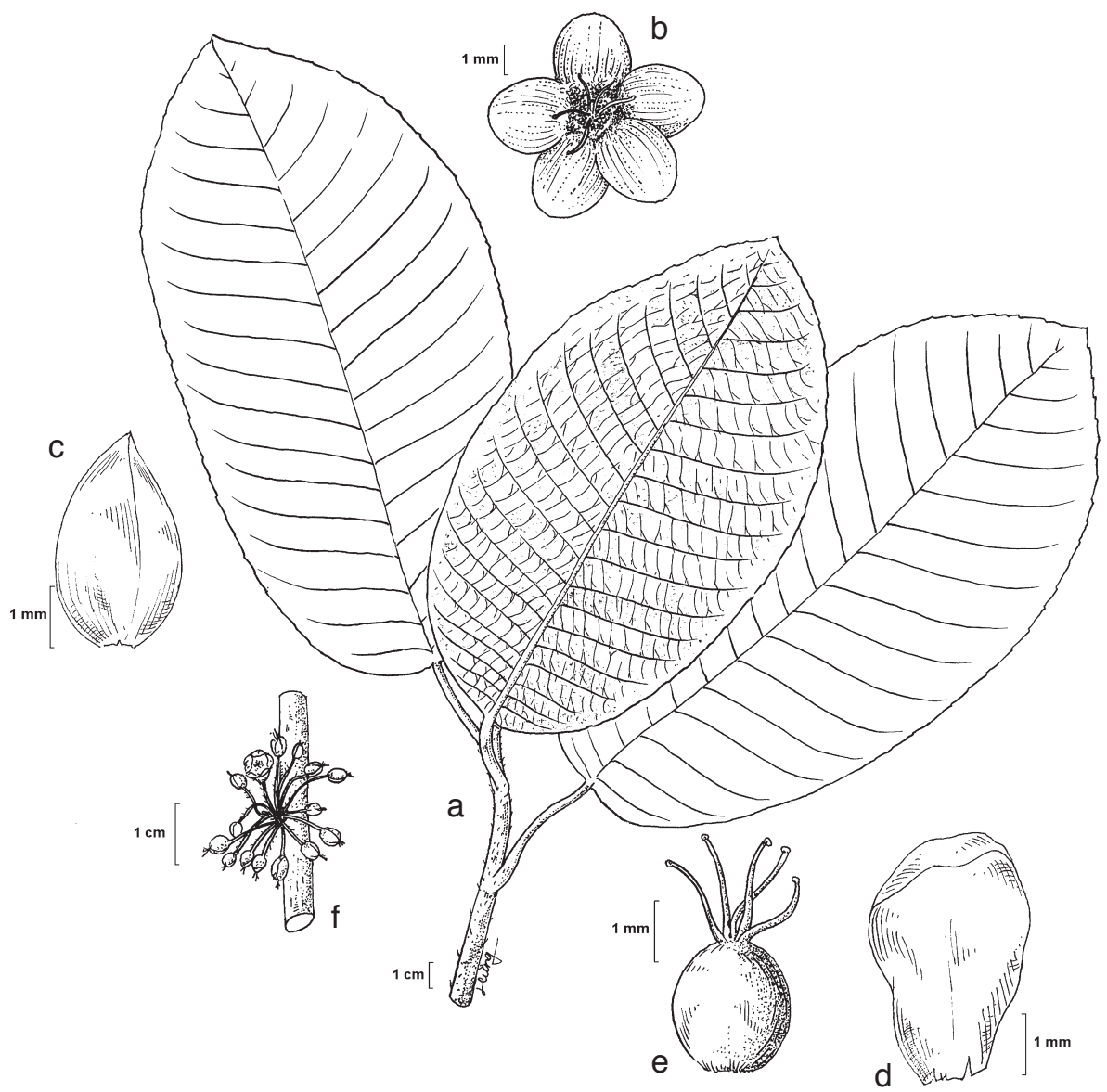

Fig. 20. Saurauia petelotii Merr. a. Branch; b. flower; c. sepal; d. petal; e. gynoecium; f. inflorescence (a: Petelot 669; b-f: Cuong 2038). Illustration by N.Q. Hung. 
5-loculed, $1.5-2$ by $1.2-1.6 \mathrm{~cm}$, glabrous; styles 5, 2-2.5 $\mathrm{mm}$ long, fused at base, free for most of their length. Fruits subglobose, glabrous.

Distribution - Cao Bang, Lao Cai, and Kontum in Vietnam. Also in Myanmar, Thailand, and China.

Habitat \& Ecology - Limestone mountain slopes in evergreen tropical rain forests. Altitude 1000-1600 m. Flowering: April to July; fruiting: August to September.

Note - This species is easily distinguished by its densely tomentose-pubescent leaves underneath and its densely pubescent ovary.

\section{Saurauia roxburghii Wall.}

Saurauia roxburghii Wall. (1831) 40; Dyer in Hook.f. (1874) 287; Gagnep. (1938) 26; Hô (1999) 410, f. 1649. - Type: Wallich Cat. No. 1467 (iso F), Sillet, 1829, fl.

Saurauia poilanei Gagn. (1938) 25. - Type: Poilane s.n. (n.v.), Vat-tron, Luong Dien, Thua Thien Hue.

Treelets 5-8 m tall. Branchlets scattered strigose, younger parts scurfy pubescent. Petioles $2.5-4.5 \mathrm{~cm}$ long, scattered strigose. Lamina membranaceous to chartaceous, obovate to broadly elliptic, $10-26$ by $5-10.5 \mathrm{~cm}$, apex acuminate, acumen $0.5-1.5$ $\mathrm{cm}$ long, margins finely serrulate to serrate, base cuneate to rounded-cuneate, adaxially glabrous, abaxially scattered strigose along major veins, lateral veins 9-17 pairs. Inflorescences $1.5-8 \mathrm{~cm}$ long, normally densely crowded, 3-12-flowered; peduncles $0.6-5.5 \mathrm{~cm}$ long; bracts ovate to linear, $1-2 \mathrm{~mm}$ long; pedicels $0.4-2.75 \mathrm{~cm}$ long; peduncles, pedicels and bracts scurfy pubescent. Flowers pink; sepals 5, ovate to rounded ovate to obovate, $3.5-5.5$ by $2.5-4.5 \mathrm{~mm}$, puberulent at base outside, glabrous on the upper part; petals 5, pink, obovate, $5-7$ by $2.5-3.8 \mathrm{~mm}$; stamens $20-45$, filaments 1-2 mm long, anthers $0.5-0.85 \mathrm{~mm}$ long, ovary ovoid, (3- or) 4- (or 5-)loculed; styles ( 3 or) 4 (or 5), 1.5-3.2 mm long, connate at base half to three-fourth their length. Fruits glabrous.

Distribution - Throughout Vietnam. Also in Nepal, India, Myanmar, Thailand, Cambodia, Laos, China (including Taiwan), Japan, and Malaysia.

Habitat \& Ecology - Secondary and primary evergreen tropical rain forest. Altitude 150-1700 m. Flowering: April to June; fruiting: August to October.

Note - Saurauia roxburghii is very closely related to $S$. tristyla, which can be distinguished by its more densely crowded inflorescences, its smaller flowers, its 4 or 5 styles, which are fused at base half to three-fourth their length. On the other hand, $S$. tristyla is characterized by the lax nature of the inflorescences and its more consistently 3-styled ovary.

\section{Saurauia tristyla DC.}

Saurauia tristyla DC. (1822) 423, t. 4; Dyer in Hook.f. (1874) 287; Gagnep. (1938) 25; C.F. Liang (1984) 296; J.J. Peng \& F.Y. Lu (1996) 661, f. 291. - Type: Wallich 1466 (iso K), India, fr.

Trees 6-10 m tall. Branchlets scattered strigose-pubescent, denser on the younger parts. Petioles 2-4.5 cm long, scattered strigose. Lamina membranaceous to chartaceous, obovate to elliptic-obovate, $9-20$ by $4-8.5 \mathrm{~cm}$, apex acuminate, acumen $0.5-1.5 \mathrm{~cm}$ long, margins finely serrulate to serrulate-denticulate, base cuneate, adaxially glabrous, 
abaxially scattered strigose along major veins, lateral veins 8-13 pairs. Inflorescences $1.2-5 \mathrm{~cm}$ long, normally lax, 1-10-flowered; peduncles 1-3 mm long; bracts ovatelanceolate to obovate, $0.5-1 \mathrm{~mm}$ long; pedicels $1.8-2.2 \mathrm{~cm}$ long. Flowers pinkishwhite; sepals 5 , glabrous, broadly ovate to obovate, $5-7.5$ by $3.6-5.5 \mathrm{~mm}$; petals 5 , ovate to oblong, pink to pale-pink, $7-9$ by $4-5 \mathrm{~mm}$; stamens $22-35$, filaments $2-3.5$ $\mathrm{mm}$ long, anthers $1.5-1.8 \mathrm{~mm}$ long; ovary globose, $1.6-2.8$ by $1.6-2.5 \mathrm{~mm}, 3$ - (or 4-) loculed; styles 4.5-7 mm long, 3 (or 4), free to fused at base about one-third their length. Fruits glabrous, 3-lobed, ovoid.

Distribution - Hue, Quang Tri, and Kontum provinces of Vietnam. Also in Laos, Thailand, China (Taiwan), Philippines, Malaysia, Indonesia.

Habitat \& Ecology - Evergreen tropical rain forest, often on soil and rocky limestone mountain slopes. Altitude 50-1200 m. Flowering: April to July; fruiting: August to November.

\section{ACKNOWLEDGEMENTS}

We wish to express our sincere thanks and appreciation to Drs. Peter F. Stevens, Peter Hoch, and P. Mick Richardson, who kindly made comments and suggestions on the manuscript and offered useful criticisms. Thanks are also expressed to the Vietnam Forest Protection Department, Cuc Phuong National Park, Bach Ma National Park, Tam Dao National Park, and Hoang Lien Son National Park, for permission in researching specimen within the collection of Actinidiaceae material. To the directors and curators of A, F, HN, HUN, K, L, MO, P, US herbaria, we thank you for the kind loan of the Actinidiaceae material for our study.

Research for this paper was supported, in part, by the training fund of the University of Illinoisbased ICBG (International Cooperative Biodiversity Groups) grant 2 UO1 TW 00101501 (administered by the Fogarty International Centre through funds from the United States National Institutes of Health, the National Science Foundation, and the United States Department of Agriculture Foreign Agricultural Service), the Russell E. Train Education for Nature Program of the World Wild Life Fund for Nature (WWF - EFN), the Henry Luce Foundation, and the Missouri Botanical Garden, to the first author. These financial supports are greatly acknowledged and thanked.

\section{REFERENCES}

Anderberg, A.A., C. Rydin \& M. Kallersjo. 2002. Phylogenetic relationships in the order Ericales: analyses of molecular data from five genes from the plastid and mitochondrial genomes. Amer. J. Bot. 89: 677-687.

Bân, N.T. 2003. Actinidiaceae. In: N.T. Bân (ed.), Cac Loai Thuc Vat Vietnam (Checklist of plants of Vietnam) 2: 433-435. Agricultural Publishing House, Hanoi.

Bentham, G. 1861. Flora Hongkongensis - A description of the flowering plants and ferns of the Island of Hongkong. Reeve \& Co., London.

Cronquist, A. 1981. An integrated system of classification of flowering plants. Columbia University Press, New York.

De Candolle, A.P. 1822. Mémoire sur la famille des Ternstroemiacées et en particulier sur le genre Saurauja. Mém. Soc. Phys. Genève 1: 421, t. 7.

De Candolle, A.P. 1823. Mémoire sur la famille des Ternstroemiacées et en particulier sur le genre Saurauja: 29, 31. Chez J.J. Pachoud, Imprimeur-Libraire, Genève.

Diels, L. 1931. Miscellanea Sinensia. Notizbl. Bot. Gart. Berlin-Dahlem 11: 208-215.

Dressler, S. \& C. Bayer. 2004. Actinidiaceae. In: K. Kubitzki (ed.), Families and genera of vascular plants 6: 14-18. Springer.

Dunn, S.T. 1906. Decades Kewensis I - Plantarum novarum in Herbario Horti Regii Conservatarum. Bull. Misc. Inform. Kew 1: 1-15. 
Dunn, S. T. 1911. A revision of the genus Actinidia. J. Linn. Soc., Bot. 39: 394-490.

Dyer, W.T.T. 1874. Ternstroemiaceae. In: J.D. Hooker, Fl. Brit. India 1: 279-294. Reeve \& Co., London.

Finet, A.E. \& F. Gagnepain. 1906a. Espèces nouvelles de l'Asie orientale. Bull. Soc. Bot. France 53: $573-576$.

Finet, A.E. \& F. Gagnepain. 1906b. Contributions à l'étude de la flore de l'Asie orientale. Bull. Soc. Bot. France 52: 1-54.

Finet, A.E. \& F. Gagnepain. 1907. Dilléniacées. In: M.H. Lecomte (ed.), Fl. Indo-Chine 1: 12-28. Masson \& Cie., Paris.

Gagnepain, F. 1938. Dilléniacées (Saurauia \& Actinidia). In: H. Humbert (ed.), Suppl. Fl. Indo-Chine 1: 17-29. Muséum National d'Histoire Naturelle, Paris.

Gardner, G. \& J.G. Champion. 1849. Descriptions of some new genera and species of plants, collected in the island of Hong Kong by Capt. J.G. Champion. Hooker's J. Bot. Kew Gard. Misc. 1: $240-246$.

Gilg, E. \& E. Werdermann. 1925. Dilleniaceae. In: A. Engler \& K. Prantl, Nat. Pflanzenfam. ed. 2, 21: 7-47. Engelmann, Leipzig.

Hance, H.F. 1885. Spicilegia Florae Sinensis: Diagnoses of new and habitats of rare or hitherto unrecorded Chinese plants. J. Bot. 23: 321-330.

Hô, P.H. 1999. Actinidiaceae. In: P.H. Hô, Cay Co Vietnam (An illustrated Flora of Vietnam) 1: 408-410, f. 1639-1649. Junior Publisher, Hanoi.

Hooker, J.D. 1874. Flora of British India 1: 279-294. Reeve \& Co., London.

Hooker, W.J. 1849. Descriptions of some new genera and species of plants, collected in the Island of Hong Kong by Capt. J.G. Champion, 95th Regt.; by the late George Gardner, Esq., F.L.S., Superintendent of the Royal Botanical Garden, Ceylon. Hooker's J. Bot. Kew Gard. Misc. 1: $240-246$.

Hutchinson, J. 1926. The families of flowering plants I. Dicotyledons. MacMillan Co., Ltd., London. ICBN - see McNeill et al., 2006.

Kurz, W.S. 1873. New Burmese plants (Ternstroemiaceae). Part II. J. Asiat. Soc. Bengal 42: 59-60.

Kurz, W.S. 1877. Ternstroemiaceae. In: W.S. Kurz (ed.), Forest Flora of British Burma 1: 102-104. Office of the Superintendent of Government Printing. Calcutta.

Li, H.-L. 1943. Notes on the flora of Indo-China. J. Arnold Arbor. 24: 362-374.

Li, H.-L. 1952. A taxonomic review of the genus Actinidia. J. Arnold Arbor. 33: 1-61.

Li, J., H. Huang \& T. Sang. 2002. Molecular phylogeny and infrageneric classification of Actinidia (Actinidiaceae). Syst. Bot. 27: 408-415.

Li, J., X. Li \& D.D. Soejarto. 2006. Actinidiaceae (draft). In: Fl. China vol. 12 at http://www.fna. org/china/mss/treatments.htm

Liang, C.F. 1984. Actinidiaceae. In: Feng Kuo-mei (ed.), Flora Reipublicae Popularis Sinicae 49, 2: $195-334$.

Lindley, J. 1836. A natural system of botany ed. 2. Longman, London.

McNeill, J., F. R. Barrie, H.M. Burdet, V. Demoulin, D.L. Hawksworth, K. Marhold, D.H. Nicolson, J. Prado, P.C. Silva, J.E. Skog, J. H. Wiersema \& N.J. Turland. 2006. International Code of Botanical Nomenclature (Vienna Code) adopted by the Seventeenth International Botanical Congress Vienna, Austria, July 2005. Koeltz Scientific Books, Königstein. Regnum Veg. 146.

Merrill, E.D. 1922. New or noteworthy Bornean plants. J. Straits Branch Roy. Asiat. Soc. 86: $312-342$.

Merrill, E.D. 1924. New species of plants from Indo-China. Univ. Calif. Publ. Bot. 10: 423-430.

Merrill, E. D. 1938. New or noteworthy Indo-Chinese plants. J. Arnold Arbor. 19: 21-70.

Paul, T.K. 1993. Actinidiaceae. In: B. D. Sharma \& M. Sanjappa (eds.), Flora of India 3: 194-203. Botanical Survey of India, New Delhi.

Peng, J.-J. \& F.-Y. Lu. 1996. Actinidiaceae. In: Flora of Taiwan ed. 2, 2: 656-661, f. 291. Taipei, Taiwan.

Soejarto, D.D. 1980. Revision of South American Saurauia. Fieldiana, Bot., n.s., 2: 1-141. 
Soejarto, D.D. 2004. Actinidiaceae. In: N. Smith, S.A. Mori, A. Henderson, D.W. Stevenson \& S.V. Head (eds.), Flowering plants of the Neotropics 9, 10. New York Botanical Garden and Princeton University Press.

Soltis, D.E., P.S. Soltis, M.W. Chase, M.E. Mort, D.C. Albach, M. Zanis, V. Savolainen, W.H. Hahn, S.B. Hoot, M.F. Fay, M. Axtell, S.M. Swensen, L.M. Price, W.J. Kress, K.C. Nixon \& J.S. Farris. 2000. Angiosperm phylogeny inferred from $18 \mathrm{~S}$ rDNA, rbcL, and atpB sequences. Bot. J. Linn. Soc. 133: 381-461.

Van Tieghem, M.P. 1899. Sur les genres Actinidie et Sauravie considérés comme types d'une famille nouvelle, les Actinidiacées. Ann. Sci. Nat., Bot. sér. 8, 10: 137-140. Paris.

Wallich, N. 1831. Plantae Asiaticae Rariores 2: 40, 77. London.

Willdenow, C.L. 1801. Drei neue Pflanzengattungen beschrieben. Ges. Naturf. Freunde Berlin Neue Schriften 3: 403-409.

Woodland, D.W. 2000. Contemporary plant systematics, ed. 2. Andrews University Press, Berrien Springs.

\section{IDENTIFICATION LIST}

$$
\begin{aligned}
& \text { Actinidia } \\
& \text { A1 }=\text { callosa } \text { var. discolor } \\
& \text { A2 }=\text { fortunatii } \\
& \text { A3 }=\text { fulvicoma } \text { var. fulvicoma } \\
& \text { A4 }=\text { fulvicoma } \text { var. hirsuta } \\
& \text { A5 }=\text { indochinensis } \\
& \text { A6 }=\text { latifolia } \\
& \text { A7 }=\text { petelotii } \\
& \text { A8 }=\text { rubricaulis }
\end{aligned}
$$

$$
\begin{aligned}
& \text { Saurauia } \\
& \begin{aligned}
\text { S1 } & =\text { armata } \\
\text { S2 } & =\text { macrotricha } \\
\text { S3 } & =\text { napaulensis } \\
\text { S4 } & =\text { petelotii } \\
\text { S5 } & =\text { roxburghii } \\
\text { S6 } & =\text { tristyla }
\end{aligned}
\end{aligned}
$$

Anderson 1287: S2 - Averyanov 7: S3; 152: S3; 461: S3; 938: S5; 1340: S4; 1720: S3; 1761: A3; 2695: A7; 4073: A6; 4514: S3; 4567: A6; 5283: A3; 5588: S6.

Bac 2100: S4 - Balick \& Nanakorn 3435: S3 - Bartholomew 36: S3 - Beaman 9576: S6 - Binh \& Cuong 1528: S1.

Cavalerie \& Fortunat 2350: A2 - Chang 4878: A1 - Charoenchai 296: S5 - Chen Shaoqing 15863: A7 - Chen-Huanyong 10679: A4 - Chew 878: S6 - Chun 51334: A2 - Chung 7270: A6 - Clarke 37966: S2 - Clemens 3406: S5; 4049: S5; 27831: A6 - Croat \& Dzu 77850: S5 - Cuong 652: S5; 2031: A3; 2032: S6; 2033: A3; 2035: S6; 2036: A3; 2037: S5; 2038: S4; 2039: S3; 2040: S2; 2041: A6; 2043: A7; 2044: S2; 2045: A8; 2046: A5; 2047: A7; 2048: A6; 2049: A5; 2050: A6; 2051: A8; 2052: A6.

d'Alleizette 201800: A6 - Daniel 4740: S5; 4949: S3 - Dao 33: A4 - Delavay 163: S3; 5152: A8 - Dran 734: S5.

Evrard 2192: S3.

Fang 2113: A8 - Farges 1946: A8 - Feng 11006: S3 - Forest 1158: S4 - Fosberg 37984: S5 - Fung 20096: A6.

Gao 1794: A6 - Geesink 7674: A6 - Geesink \& Santisuk 5415: S5 - Gressitt 1453: A6 - GuangTeam 721: A4.

Hansen \& Smitinand 12896: S4 - Hao 88037: A1 - Harder 1793: S5; 5211: S3; 5573: S3 - Hayashi 21244: A6 - Henderson 21846: S6; 32971: S6 - Henry 592: S4; 10696: A8; 11732: S1; 12124 : S5; 12126: S4 - Hiep 551: S3; 642: S5; 795: A1; 1131: A3; 1798: S6 - Hiep \& Xiem 420: S5 - Hoogland 12336: S5; 12615: S3 - How 71995: A6 - Hu 10480: S5 - Huang 242: A5 - Hui 205: A6; 370: A6 - Huq \& Mia 10287: S5; 10594: S5 - Hutchinson 570: S2.

Keenan 3933: S4 - Kerr 7766: A6; 14455: S6; 15548: A6; 15561: S6; 20871: S5 - Kiah 35014: A6 - Kingdon 20980: S2 - Koelz 4535: S3 - Koyama 48722: S3.

Lace 5936: S4 - Lakshnakara 681: S6 - Larsen 33146: S6; 33401: S6; 33536: S5 - Lecomte \& Finet 454: S3; 535: S3 - Li 8868: S3; 10811: S3; 11732: S3; 14007: S3 - Liang 62163: S5 — Lin 677: S5; 765: S5 - Loc 1501: A7 - Luo Lin-bo 792: A6. 
Maxwell 84-7: S6; 85-405: S6; 88-1212: S3 - McClure 180: S6; 5109: S6 - Middleton 335: S6; 567: S6; 1901: S6 - Minaki 9040099: S3 - Mogea 819: S6.

Nanakorn 91035: S3 - Noshiro 9755005: S3; 9755133: S5; 9840053: S3.

Petelot 669: S4; 2589: S2; 2689: S2; 3829: A7; 4406: A5; 4542: S3; 5789: S3; 5938: A5; 5940: A5; 6062: S5; 6343: A8; 6344: A8; 8363: S2; 8582: A8; 8649: A6; 8650: S4; 8651: S2; 8747: A6 — Phuong 54: S3; 354: S4; 457: S2; 628: S3; 708: A1 - Pierre 572: S5; 819: A6 - Poilane 1780: S3; 1838: S3; 4113: S3; 5536: S1; 13190: A6; 15877: A6; 16783: S3; 17004: A5; 21688 : A5; 25776: S1; 30956: S3; 31833: S4; 32683: S3; 32879: S3; 232684: S4 — Prain 400: S5.

Rock 2168: S3 - Ruse 152: S2.

Shimizu 11637: S3; 13492: S3 - Sinclair 9962: S3 - Smitinand \& Cheke 46490: S4 - Smitinand \& John 6807: S4 - Soejarto 9708: S3; 10273: S5; 10716: S5; 11421: S3; 11532: S5; 13928: A2 - Soepadmo \& Suhaimi 71: S3 - Spire 457: S5 - Students 305: S6.

Taam 783: A6; 1481: A6; 2196: A6 - Tanaka \& Shimada 11091: S6 - Trai 2708: A6 - Tsang 24120: A2; 29907: A6 - Tsang \& Fung 291: A6 - Tsiang 4108: A8 - Tso 20349: S5; 20386 : S5; 21079: S5.

Van Beusekom \& Phengkhlai 780: S6 - Van der Werff 17252: S3 - Vidal 4937: S3; 5285: S3 - Violet \& Rose 1750: S5.

Wallich Cat. 1466: S6; 1467: S5; 14691: S3 -Wang 39336: A6; 42237: A2; 44193: A2; 72122: S3; 79627: S3 - Wang \& Lin 2218: A6 - Ward 17438: S3; 17789: S3; 20782: S3; 21613: S3 - Wright 42: A6 - Wu 132: S6.

Xianghou 973: A6 - Xiong Bin 8561: A4.

Yahara 49842: S3 - Yao 9218: A1.

Zhang Shaoyao 8130: A1. 